\title{
How Accurate are Surveyed Preferences for Public \\ Policies? Evidence from a Unique Institutional Setup
}

\author{
Patricia Funk \\ Universitat Pompeu Fabra and Barcelona GSE
}

September 2012

\begin{abstract}
Opinion polls are widely used to capture public sentiments on a variety of issues. If citizens are unwilling to reveal certain policy preferences to others, opinion polls may fail to characterize population preferences accurately. The innovation of this paper is to use unique data to measure biases in opinion polls for a broad range of policies. I combine data on 184 referenda held in Switzerland between 1987 and 2007, with postballot surveys that ask for each proposal how the citizens voted. The difference between stated preferences in the survey and revealed preferences at the ballot box provides a direct measure of bias in opinion polls. I find that these biases vary by policy areas, with the largest ones occurring in policies on immigration, international integration, and votes involving liberal/conservative attitudes. Also, citizens show a tendency to respond in accordance to the majority.
\end{abstract}

JEL-Codes: D03, Z

Keywords: Opinion polls, Biases, Preference Falsification, Direct Democracy

*Correspondence: Patricia Funk, Department of Economics, Universitat Pompeu Fabra, Email: Patricia.Funk@upf.edu. A previous version of this paper has been circulated as "Citizen Preferences in Private and Public: Evidence from a Large Number of Votes". I would like to thank Larbi Alaoui, Ghazala Azmat, Antonio Ciccone, Rajeev Dehejia, Gabrielle Fack, Claudio Ferraz, Stephan Litschig, Ben Olken, Torsten Persson, Alessandro Tarozzi, conference participants at the EEA meeting 2011, and seminar participants at University of Zuerich, University of Oslo and BI Norwegian Business School for helpful comments. Financial support from the Barcelona GSE Research Network and the Government of Catalonya is gratefully acknowledged. 


\section{Introduction}

In representative democracies, opinion polls are the main vehicle to extract information on voters' preferences. Since citizens cannot vote on policy issues directly, policy makers lack important information on voters' preferences on specific policies (Besley and Coate, 2008). Civic voluntarism (campaign help or contact with representatives) may help to identify voter preferences, but likely reflects the voice of the resource rich at the expense of the less privileged (Verba, Schlozman and Brady, 1995). Conventional wisdom therefore holds that sample surveys provide the closest approximation to an unbiased representation of the public view (Berinksy, 1999). How accurate are these surveys? Unfortunately, the only information available is the one expressed in the surveys (privately held opinions are unobservable), which makes it impossible to assess the truthfulness of its content. This is especially problematic since policy makers are likely to adapt their policies according to what citizens reveal in the polls. ${ }^{1}$

The innovation of this paper is to use unique data that allow to measure the accuracy of opinion polls for various types of public policies. The data come from Switzerland, the world leader in the use of direct democracy. In Switzerland, citizens vote on all major policies through referenda. The results of these ballots provide a measure of revealed preferences for policies, to which survey responses can be compared. Starting in 1987, telephone surveys have been conducted after each federal vote, covering samples of roughly 1,000 eligible voters (these surveys are called VOX-survey). ${ }^{2}$ The survey is conducted 2-3 weeks after the vote and aims to gather information about the respondents' voting behavior, with questions ranging from whether and how the respondent voted, information on political views, knowledge about the ballot, the perceived importance of the ballot and various

\footnotetext{
${ }^{1}$ Any political economy model where candidates care about re-election predicts policy effects from opinion polls, as long as they are used to extract information on voter preferences. Berinsky (2004) provides various anecdotal pieces of evidence for US politics.

${ }^{2}$ The samples are selected by random sampling based on the telephone book. Response rates to the survey fluctuate between 28 and 48 percent, and are slightly higher than the average response rate of similarly conducted telephone surveys by major news media in the US. Holbrook, Krosnick and Pfent (2007) analyze 114 telephone studies that were conducted by major American news media (ABC News, New York Times, Gallup, Washington Post etc.) between 1996 and 2005 and find an average response rate of 30 percent.
} 
socio-demographic characteristics.

The key idea of the paper is to compare, for each vote, the approval stated in the survey (= "share yes" of all respondents that indicate to have voted and reveal their result) with true approval as given by the voting result (real "share yes" per ballot). ${ }^{3}$ This difference between stated and revealed voter preferences provides a direct measure of survey bias for a broad range of policy issues. Since Swiss citizens are asked how they voted shortly after the vote, it gives rise to a clean experiment: in contrast to pre-polls, there is no incentive for the respondents to strategically answer (unless the goal is to hide the true policy preferences), and neither does the question allow for changing preferences over time. ${ }^{4}$ Therefore, any difference in approval between the vote and the post-vote survey must be caused by either, differences in the population of voters and survey respondents who declare to have voted, or citizens deliberately misreporting their preferences in surveys.

Information on revealed preferences for public policies is absent in representative democracies, because citizens don't vote on public policies directly. Even in representative democracies with direct democratic elements at the sub-federal level (e.g. California in the US), the number of votes held is typically low, covering a small set of policies. Furthermore, exit-poll data are not publicly available, which makes a more refined analysis impossible. In Switzerland, all individual-level post-vote survey data are publicly available. This will allow to shed some light on the determinants of the survey bias.

The main interest of the paper lies in quantifying the extent of the survey bias, and to relate it to the policy area of the vote. There are reasons to believe that the magnitude of the survey bias depends on the topic of the survey. Economic research has advanced the argument that people care about their image. One may therefore expect that citizens take actions that make them appear altruistic (Benabou

\footnotetext{
${ }^{3}$ The survey gives the options "Yes", "No", "No Answer", and "Don't Know" for the voting result. The "Share Yes" is calculated as the sum of "Yes" votes over the sum of "Yes" and "No" votes, to match the definition of the ballot results.

${ }^{4}$ The survey asks clearly: how did you vote in the ballot on topic X? Therefore, even if preferences change, it would not affect the answer. In contrast, a difference between the official voting result and answers in pre-polls can arise because citizens strategically mis-represent their preferences, in order to make the other citizens changing their votes; or, citizens, after learning the polling results, may change their minds on how to vote.
} 
and Tirole, 2006; Tadelis, 2011), politically correct (Morris, 2001; Loury, 2004), or in line with the consensual view (Bernheim, 1994; Kuran, 1995). Citizens with politically incorrect views, for instance, may choose not to respond to the survey, or instead, to respond but then lie in their responses. Both channels lead to a gap between stated and revealed voter preferences on socially sensitive issues. To test for potential differences in survey accuracy with respect to the policy area shall be one of the main contributions of this paper.

The Swiss data allow to measure survey accuracy for 184 federal votes. These votes cover all policy areas relevant in a mature democracy. To name a few examples, votes have been held on immigration, environmental protection, health, unemployment benefits, agriculture, the military, or various regulatory measures. The survey bias (defined as the vote-specific difference between the reported and effective share yes) is 4.7 percentage points on average. For roughly half of the votes, this survey bias is statistically significant at conventional levels. There is, however, a large variation in biases across votes. For instance, the vote with the biggest difference between stated and true preferences concerned a proposed law change to improve the conditions for working women giving birth to a child. Here, 72 percent of survey respondents state to have voted in favor, whereas the approval at the ballot was only 55 percent. More generally, precisely the policy areas which have been subject to the political correctness debate (issues on gender, race and gay rights; see Loury, 1994) show the biggest distortions in the surveys. Other policy areas (health, retirement age, direct democracy) display no significant differences between stated and revealed preferences and the surveys describe the underlying preferences well.

Historically, politically correct views had a clear left-wing connotation (pro gender equality, against racism, pro gay rights, pro environment etc.). I explicitly test the hypothesis that votes supported by the left-wing party have higher expressed yes in the survey (relative to the ballot result) compared to the votes where the left-wing party recommended a "no". The data strongly support the existence of a "liberal bias". Votes supported by the left-wing party had a too high share of "yes"-votes in the 
survey, whereas votes where the left-wing party recommended a "no" displayed a too high share of "no"-votes in the survey. The difference in the survey bias (= stated approval in the survey minus true approval) between votes that were and were not supported by the left-wing party is 5 percentage points and statistically significant. This liberal bias persists when the individual survey data are reweighted to correct for over-sampling of observable individual characteristics (including self-reported party affiliation). Therefore, selection on observables is not the driver behind this bias. Either, citizens choose to respond to the survey based on unobservables such as their privately held policy preferences, or respondents falsify their preferences in the survey. From a policy perspective, disentangling between these two channels is not that essential, since in both cases, there is not much the researcher can do to eliminate the bias in polls. Nevertheless, the data provide evidence that part of the people falsify their preferences in surveys. I compare for that votes held on the same day, ${ }^{5}$ which were perceived to be of either high or low importance for the Swiss nation as a whole. I hypothesize that for votes of small importance, there is little pressure to lie. If so, the liberal bias should be bigger in votes that were salient and regarded of high-importance. In line with this intuition, the data show that in fact, the liberal bias is only present for votes of high importance.

Next to identifying whether survey accuracy depends on the topic, the data allow to test whether surveys suffer from a conformity (or winning) bias. Since the voting result is known at the time of the survey, a natural starting point is to investigate whether votes that were accepted (majority voted "yes") have a different bias compared to the votes that were rejected (majority voted "no"). The data reveal a clear pattern: the share yes in the survey is too high for votes that were accepted, and too low for votes that were rejected. The gap between stated and revealed approval is 5 percentage point higher for votes that passed compared to the votes that were rejected, and this difference is 6 percentage point for votes accepted and rejected on a narrow margin. Irrespective of the exact

\footnotetext{
${ }^{5}$ In this case, the respondent sample is constant, since the survey asks the respondent on how he voted on all votes that were held on a given day (see Section 2).
} 
underlying behavioral motive (a desire to be on the winning-side, or a desire to be in conformity to others, Bernheim, 1994), the result stands that survey responses on policy issues are biased according to the majority view.

Last, the data allow to investigate whether the accuracy of surveys differs by culture, religion, or economic development of a geographic unit. Switzerland is a very diverse country, with differences in languages (German-, Italian-, and French-speaking areas), religions (nearly equal share of Protestants and Catholics), economic opportunities and population size (city Cantons versus more rural Cantons). It turns out that Cantons of German speaking language (and culture) display significantly higher survey biases than the other Cantons (French/Italian speaking). This suggests a role for cultural differences in survey accuracy. Also, Cantons with higher population size have lower biases on average. This is consistent with previous research showing that social pressure is particularly high in small-knit communities (Funk, 2010), which may channel into public expression of preferences. Religion, on the other hand, does not appear to matter, once culture is accounted for.

The paper relates to various strands of the literature. First, it is relevant for a growing economic literature based on survey data. Even though economists have traditionally been sceptical with regard to surveys on attitudes and preferences (Bertrand and Mullainathan, 2001), there has been a recent surge of influential papers explaining certain types of attitudes and preferences (Fong, 2001; Guiso, Sapienza and Zingales, 2003; Alesina and Fuchs-Schuendeln, 2007). This paper shows that scepticism on surveyed preferences is justified in certain policy areas (e.g. racial attitudes, attitudes on gender equality), but less so in others (preferences for direct democracy, health, or federal finances). Furthermore, the data allow to assess, how innocuous it is to compare survey-responses across cultures and religions. Second, the paper relates to a growing literature investigating the consequences of social pressure and image concerns. So far, various studies established that image concerns matter for voter participation (Gerber, 2008; Funk, 2010), contributions to charity (DellaVigna, List, and Malmendier, 2011), or worker effort (Mas and Moretti, 2009). This paper documents that opinion 
polls are particularly biased on topics with a predominant politically correct view, which is consistent with citizens caring about their image. Third, the paper complements a strand of papers (mostly in political science) which analyze the accuracy of polls in elections (e.g. Baretto, Guerra, Marks, Nuno and Woods, 2006; Stromberg, 2008; Hopkins, 2009). The key addition to these papers it to add knowledge on the accuracy of polls on issues. The setting of a direct democracy gives rise to a measure of true preferences (as revealed at the ballots), to which survey responses can be compared. Forth, a related literature in political science explores the role of item-non response for the survey quality of a given respondent sample (Berinsky, 1999; 2004). The data at hand allow to go one step further by contrasting survey responses to the true underlying preferences of the voting population. In line with Berinsky (1999; 2004), I find poor survey quality on issues involving race. Last, the paper relates to a strand of laboratory experiments that investigate the nature of lying (Gneezy, 2005; Lundquist, Ellingsen, and Johannesson, 2009). This paper suggests that for some policy areas, citizens prefer to hide their true opinion, even if it is merely a survey conducted by telephone.

The rest of this article is structured as follows. Section 2 describes the data and the gaps between stated and true approval for public policies. Section 3 investigates two major sources of bias. Section 4 investigates Cantonal differences in survey accuracy and Section 5 concludes.

\section{Data}

\subsection{Official Voting Results}

For Swiss citizens, having a say on politics is almost daily business. Switzerland has a long tradition in direct democracy; at the federal level alone, citizens have voted on more than 300 ballots in the last 50 years. Citizens can propose an initiative for a partial or total revision of the federal constitution. In addition, they can request a referendum about all laws issued by the federal government if 50,000 signatures are collected. Furthermore, a voter referendum is mandatory for any changes to the consti- 
tution and all international treaties. As a consequence, citizens vote on federal ballots several times each year.

In Switzerland, every person older than 18 is allowed to vote (before March 1991, the minimum age was 21). The eligible voter receives all the documents delivered by mail at home. These documents include all relevant information on the ballots (there are usually a couple of ballots bundled for a given voting day), such as the precise questions, the arguments for and against the propositions, a printed version of the parliamentary debates (if any) and often outside opinions by interest groups. ${ }^{6}$

Hence, Swiss citizens have easy access to information about the ballots both through the distributed documents and discussions in the media. Placing the ballot is also quite convenient. In contrast to the US, no registration to vote is necessary at all. Since 1995, the voter has additionally granted the option to vote by mail, in addition to placing the documents at the voting booth. Voter turnout in the last 20 years is 42 percent on average, with a large variation depending on the topic.

On the webpage of the federal authorities (http ://www.ch.ch/abstimmungen_und_wahlen/), all federal votes ever held are listed. Information on the votes include: the title, the date, the number of eligible voters, the number of effective voters, the number of valid votes, the number of empty votes, the number of yes votes and the number of no votes. The "Share Yes"-Votes is calculated as the number of yes votes in proportion of the total number of valid non-empty votes, and the "Share No"Votes is calculated as the number of no votes in proportion of the total number of valid (non-empty) votes. The "Share Yes" and "Share No" sum up to 100 percent. The main variable of interest is the approval for each vote measured as the "Share Yes", which is to be compared to the stated approval in the VOX-Survey.

\footnotetext{
${ }^{6}$ These documents can be accessed online at http://www.ads.bar.admin.ch/ADS/showHome.do.
} 


\subsection{The Post-Election Surveys ("VOX-Surveys")}

Since 1977 "Vox" surveys have been conducted after each federal vote. These surveys are conducted with samples of roughly 1,000 eligible voters (700 voters until 1987) and take place during the two or three weeks following the vote. As described in the technical documentation on the VOX surveys, the basis for selecting households is the Swiss telephone book. A random sample stratified by language area (German-speaking, French-speaking, Italian-speaking) is applied and households are contacted until roughly 1,000 respondents have been gained. Response rates fluctuate between 25 and 48 percent for the surveys conducted between 1998 and $2007 .{ }^{7}$

The main objective of these post election surveys is to understand the motives underlying the individual voting decision, and possible connections with the knowledge of the individuals. Most relevant for my study, the VOX survey asks 1) participation at the last federal votes, and 2) voting decisions.

As for 1), the question on participation is framed in a way to reduce lying. Precisely, the text is: "It is well known that for these types of [federal] votes, many times less than half of the people vote. Citizens have other obligations as well. Was it possible to you to participate in the federal vote from the date [DD.MM.YYYY]?" Answers are: Yes, No, don't know, no answer. As for 2), the precise question was: "How did you vote on the federal ballot [title X]"? Possible answers are Yes, No, Empty, Don't know, No Answer. In 2, all votes that were bundled on a given voting day are included. Hence, a respondent gives answers for all these votes.

Apart from these questions directly related to the vote, the survey also asks for various aspects relating to the voting decision such as knowledgeability on the topic, types of media consulted prior to the decision, the perceived importance of the vote or awareness of the favorite party's recommendation. An extensive set of questions aimed to gather individual characteristics (age, education, marital status, profession etc.) completes the questionnaire.

\footnotetext{
${ }^{7}$ Technical reports are not officially available for the earlier votes.
} 


\subsection{The Survey Bias}

To compare approval in the survey for a certain vote with the one revealed at the ballot box, I first define the "Share Yes" in the Survey in an equivalent manner to the "Share Yes" of the voting result. That means taking the number of yes votes (from citizens who indicate to have voted) divided by the sum of yes and no votes. The key variable of interest is the difference between the "Share Yes" in

the Survey and the "Share Yes" from the official voting outcome, which I define as "Survey Bias". A positive survey bias indicates that the approval stated in the survey is bigger than the official one, and a negative survey bias indicates the opposite.

I start comparing official voting outcomes with stated voting outcomes for all votes (initiatives and referenda) held in 1987 or later, where the VOX-survey had a sample size of roughly 1,000 citizens. The latest available data were VOX-surveys conducted in 2007, which gives a sample of 187 votes in total, spanning all relevant policy areas in the last 20 years. Since three votes (Nr. 462, 463, 464) have an identical reported share yes, I drop these votes due to high likelihood of error. That leaves a sample of 184 valid votes.

To get a sense of the magnitude of these gaps, Figure 1 displays the kernel density. As can be seen therefrom, the reported share-yes is slightly bigger than the actual share yes, with a wide variation across different votes (the maximum difference between reported and real share yes is nearly 20 percentage points).

— insert Figure 1 about here -

What are likely sources for these biases? One candidate could be that the sample of respondents to the VOX surveys is unrepresentative in terms of individual characteristics. To investigate this possibility, I compare the respondents' characteristics in terms of age, gender, religion, language and education with a representative sample of the Swiss population. Note that here, the right comparison 
is between all survey respondents (voters and non-voters) and the Swiss population. Information on the latter can be gained by using existing data on a random sample of 5 percent of the Swiss citizenry (called "Public Use Sample"), compiled by the Swiss Federal Office of Statistics for various years. To ensure anonymity, the PUS uses age classes of the respondents. ${ }^{8}$ Subsequently, I focus on individuals with 20 years of age or more, in both, the VOX surveys and the PUS data.

— insert Table 1 about here —

As shown in Table 1, VOX respondents are quite similar to the random PUS-sample of Swiss citizens. In the year 1990, the share of protestants and the share of highly educated in the survey are slightly higher than in the population counterpart, and in the year 2000, the share of elderly people is additionally over-represented at the cost of the younger. Overall, however, the differences in average characteristics between survey respondents and the population sample are small.

To asses the role of sample selection in generating the observed survey biases, I re-weight all the survey samples to match the population precisely on religion, age above 60 , and higher education (where the highest deviations have been found). As can be seen from Figure 2, the survey bias gets reduced somewhat, but but there is still a large variance.

— insert Figure 2 about here -

As an alternative strategy, I exploit the fact that several votes with distinct surveys have been held in each year. This allows to analyze, which part of the within-year variation in the "Survey Bias" is explained by within-year variation in the over-representation of observable individual characteristics (assuming that the population characteristics are roughly constant within a given year). As it turns

\footnotetext{
${ }^{8}$ The PUS age classes are 0-4, 5-9, 10-14, 15-19, 20-24, 25-29, 30-34, 35-39, 40-44, 45-49, 50-54, 55-59, 60-64, 65-69, 70-74, 75-79, 80 years and older.
} 
out, variation in the composition of the survey respondent samples explains at most 8 percent of the variation in the Survey Bias within years. Furthermore, I investigate whether differences in overrepresentation of voters, or item-non response in the voting result can explain the different gaps across surveys. ${ }^{9}$ The answer is no. Less than 10 percent of the variation in the survey biases across votes can be explained by differences in the respondent sample, differences in the over-representation of voters or differences in the degree of item-non-response (all results available upon request). Last, I investigate the role of survey non-response (= share of contacted people which refused to respond to the survey), which varies across surveys (see Appendix Table 1 for summary statistics of the VOX-surveys). There is no significant correlation between refusal rates and the survey biases overall.

This evidence suggests that neither variation in the survey composition of observable individual characteristics, nor differences in over-representation of voters, item-non response or overall response rates to the surveys can explain a significant part of the variation in survey biases. I suspect the topic of the vote to matter, and will investigate this in the next section.

\section{Two major Biases: Liberal Bias and Conformity Bias}

To illustrate the votes with particularly large survey biases, Appendix table 2 reports the 184 valid votes, sorted by the gap between stated and real share yes. Together with this difference, the table reports the VOX Number, the policy area, the title of the proposition, the year of the vote, the official share yes of the voting result (Yes Off.), the reported share yes in the survey (Yes Rep.), the difference between the two (Diff), and the absolute value thereof (Diff Absolute). To see whether the gap between the reported and true share yes is statistically significant, I conduct a T-Test for each vote. The P-Value indicates whether, based on she (survey) sample share yes, the null hypothesis

\footnotetext{
${ }^{9}$ From research on elections, it is known that there are usually more voters in the survey-samples compared to the share of voters in the population (Karp and Brockington, 2005; Holbrook and Krosnick, 2010). The same pattern is found for the current surveys, where the share of voters in the survey is on average 9 percentage points higher than official voter turnout. However, as can be seen from the summary statistics in Appendix Table 1, there is substantial variation in the difference between reported and real turnout across surveys.
} 
(population mean equals the known true share yes as given by the voting result) can be rejected. As can be seen from Appendix table 2, the null is rejected for roughly half of the votes at standard levels of significance. ${ }^{10}$

Which are the votes with the biggest gaps? From visual inspection, it looks like there are quite a few votes in the area of environment, immigration and redistribution, where the differences in stated and real ballot outcomes are high. To make a more systematic comparison, I define 12 broad policy areas, which are relevant beyond the Swiss context. These policy areas are international integration, immigration, military, protection environment, nuclear energy, federal budget, direct democracy, health, redistribution, retirement age, gender equality and liberal attitudes. I selected all votes in a policy area that had either the same or the opposite goal (e.g. either to facilitate or make more difficult immigration; either increase or decrease the size of the Swiss army etc.) Since framing of a ballot may matter (see Buetler and Marechal, 2007), I display the votes with opposing goals separately. Appendix table 3 shows the selection of the votes, per policy area. Overall, 92 votes could be assigned to these 12 policy areas, which leaves another 92 unclassified votes. Every selection process is to a certain degree subjective. To make this process as transparent as possible, I describe the goal of all 184 the votes (including the unclassified ones) in the Appendix.

Subsequently, I would like to test whether the Survey Bias differs by policy area. The model I estimate is the following:

$$
Y_{i j t}=\beta_{j} \cdot D_{j}+\varepsilon_{i j t}
$$

The dependent variable is the Survey-Bias (= the difference between the stated "Share-Yes" in the survey and the effective "Share-Yes" of the voting result) per vote $i$ that falls into policy area $j$ and was voted upon in year t. $D_{j}$ is a dummy for each of the 12 policy areas. Standard errors are clustered

\footnotetext{
${ }^{10}$ At the $1 \%$ level of significance, I can reject the null for 85 votes, and at the $5 \%$, for 67 votes.
} 
at the voting-day level, to account for possible correlation of errors within a given survey sample.

— insert Table 2 about here -

Table 2 first column shows the differences in survey biases by policy area. As can be seen therefrom, the survey bias is positive and relatively high for votes aiming at fostering international integration (5.6 percentage points), against nuclear energy (5.2 percentage points), for the protection of the environment (3.7 percentage points), pro gender equality (6.7 percentage points), or two votes involving a liberal attitude (8.5 percentage points). These last two votes with very high survey biases involved giving more rights to homosexual couples and liberalizing sexual rights of teenagers. High negative survey biases are found for votes that target to restrict immigration (-5.1 percentage points). Here, the share of respondents which admit to have voted for tighter immigration laws is lower in the survey compared to the ballot box. Finally, note also that there are some policy areas (health, retirement age, direct democracy, federal finances), where there are no significant gaps between survey approval and real approval. Unsurprisingly, I can reject the Null that the gaps are the same across policy areas at the $1 \%$ significance level.

What are the reasons for these biases? A natural guess is that people with certain preferences (e.g. against immigration) do not respond to the survey, or they do respond but lie. However, it could also be the case that over-representation of individuals with certain characteristics explains these gaps. As shown in Table 1, the share of protestants, the share of elderly, and the share of highly educated is sightly higher in the survey compared to the shares in the census.

To assess the relevance of sample selection for the observed differences across policy areas, I reweight the data, as is standard in polling research. ${ }^{11}$ I correct for over-representation of elderly, the

\footnotetext{
${ }^{11}$ To be precise, I re-weight the complete survey (including voters and non-voters) to match the population counterpart on certain characteristics for each vote separately. Then, I newly calculate the "Share-Yes" for the citizens who indicate to have voted. The correction for over-sampling of one specific characteristic in Stata can be done by either specifying poststrata within svy-estimation and indicating poststrata weights (see Levy and Lemeshow, 1999, p. 196 ff. for a
} 
share of protestants, and the share of highly educated (column (2)). As can be seen from Table 2, column 2, the biases from the re-weighted samples are often somewhat smaller, but do not disappear. Note that this type of re-weighting procedure corresponds to the classic strategy used by most of the major US news media including New York Times, Gallup/CNN/USA today etc. (Blumenthal, 2004). There, opinion polls are weighted to match the U.S. census for gender, race, education and usually some geographic classification. Self-reported party affiliation is typically not used for re-weighting, because it is subject to error itself. Since I know the true voter preferences for the 184 surveys, it is nevertheless interesting to see whether the biases disappear if data are re-weighted according to selfreported party-identification. It turns out that the average share of self-declared left-wing voters in the survey (29 percent) is higher than the average share of left-wing vote shares in parliamentary elections (21 percent). Either, left-wing voters are more willing to respond to surveys, or some (plausibly ultra) right-wing voters do not indicate their favorite party. ${ }^{12}$ Should the second explanation have some truth, then the share of self-declared left-wing voters in the survey is higher than the real share of left-wing voters in the survey, and re-weighting the survey data to match the left-wing vote shares in parliamentary elections weights down too much the left-wing voters views'. Having this caveat in mind, column (3) presents the results when over-representation of left-wing voters in the surveys is corrected for. Many biases still persist, and the one on budget balance even gets larger. Last, I investigate the sensitivity of the results with respect to controlling for the voting result (ballot accepted/rejected), over-representation of voters in the survey (= turnout survey - turnout ballot) and

concrete example); or, if one aims to correcting oversampling of various individual characteristics (as is done in Table 2), one can use a raking procedure. Apart from what is shown in Table 2, I also corrected for individual characteristics separately (all results available upon request), and found that correcting for education affects the estimates most. I cross-checked which of the individual characteristics matters most for voting decisions. Indeed, for many policy areas, the effect of having a higher education on the probability to vote yes is the most important explanatory variable. One caveat is that data on population shares are only available at the decennial level, which forces me to use interpolation to receive information on population shares for all the years. I check, however, whether interpolation seems to be a major drawback or not. For this, I select the policy areas, in which votes have been held in the years 1990 and 2000 (where I know the population characteristics exactly). The difference between weighted and unweighted estimates (per policy area) is very comparable, for the votes in the years 1990 and 2000, and the full sample with interpolated values. Therefore, using the full dataset seems justified. All results available upon request.

${ }^{12}$ The share of self-declared left-wing voters is calculated in percentage of all survey respondents who indicate a favorite party. 
the share of item non-response in the voting result across surveys (column (4)). The magnitude of the estimated coefficients are sometimes affected, but the results remain qualitatively similar. Summing up, the accuracy of the post ballot survey differs by topic. The largest biases occur in the votes on international integration, immigration, gender equality and votes with a liberal attitude involved. These are the policy areas where a politically correct view is most obvious. Preferences on direct democracy, health, or the retirement age, however, appear to be less contaminated in surveys.

From visual inspection, it looks like liberal policies tend to have a positive gap. As shown in column (5), the policy areas with the biggest positive gaps (international integration, immigration, liberal attitudes) were largely supported by the left-wing party. That raises the question about existence of a liberal bias. To investigate a possible liberal bias systematically, I define a dummy variable that takes the value of 1 if the vote was supported by the left-wing party and 0 otherwise. Votes where the left-wing party made no recommendation are coded as a missing value (14 votes in total).

— insert Table 3 about here -

Table 3 first column shows that votes that were supported by the left-wing party had 5.4 percentage point higher approval than the votes where the left-wing party recommended a "no". As can be seen from the constant, votes where the left-wing party recommended a "no" had a negative survey bias (stated - true approval) of -1.9. Votes where the left-wing party recommended a yes had a positive average survey bias of $3.4(=5.4-1.9)$, which is statistically different from zero. The result that votes supported by the left-wing party have a higher approval in the survey (I call this "liberal bias") is robust to including year fixed effects, and controlling for the result of the vote, either in a binary way (vote rejected/approved), or linear way (share yes). It also persists when identified from withinsurvey sample variation (column 5). Columns 6 to 7 account for differences in the composition of survey respondents, (with regard to age, religion, and education (column 6), and self-declared partyaffiliation (column 7)). Again, re-weighting the data according to self-reported party affiliation is 
likely to bias the results towards not detecting any liberal bias. Nevertheless, the estimated liberal bias persists. ${ }^{13}$

A natural interpretation of the results is that left-wing parties support more politically correct views (Liberal Attitude, Pro-Environment, Pro-Redistribution, Pro-Immigration etc.) and this causes people with politically incorrect views either not to respond to the survey, or to respond and falsify their preferences. Under which conditions are citizens likely to lie? Of first order priority seems to be the importance of the vote. Votes with large consequences for the country are more salient and also more frequently discussed in the media. To admit a politically incorrect view seems more costly in this situation. Since the VOX survey asks for the perceived importance of the vote for Switzerland as a whole, I can classify the votes according to whether they were ranked above or below the mean importance of the vote. The dummy variable Importance Vote takes a value of 1 if the vote was above the mean, and 0 otherwise. As can be seen in column (8), the bias is significantly larger for important votes. Column (9) relies on variation across votes that were held on the same day. Here, the set of survey respondents is the same. Again, for all votes supported by the left-wing party, only the important ones have a bias. This is suggestive of survey-respondents falsifying their preferences according to liberal views, which may correlate with political correctness.

Another apparent bias comes from knowing the result of the vote. Accepted ballots have a higher positive survey bias than rejected ballots. Table 4 investigates the nature of this bias in more detail.

— insert Table 4 about here -

Table 4 displays regression results where the dependent variable is the survey bias (stated - true approval) and the variable of interest a dummy-variable "Vote Accepted", which takes a value of 1 if more than $50 \%$ of the electorate said yes, and 0 otherwise. As can be seen from column (1), votes that

\footnotetext{
${ }^{13}$ Note also that estimated interaction terms recommendation Left-Wing Party times turnout gap, and recommendation Left-Wing Party times share empty votes are insignificant. Therefore, the liberal bias is unlikely to be caused by item non-response or non-voters being more liberal and pretending to have voted.
} 
were accepted showed a 4.8 percentage points bigger survey bias than the votes that were rejected. Interestingly, for the votes that were rejected (see constant term), there was no bias at all. Columns (2) to (5) add year fixed effects, control for the voting result in a non-binary way, and also control for the left-wing parties' recommendation. The magnitude of this bias is quite robust across various specifications. Column (6) add controls for the topic of the vote, and column (7) uses variation of the votes for a given day (and therefore for a fixed respondent sample). If it is the case that passage of a vote matters, then the effect would also hold for narrowly accepted or rejected votes. Column (8) shows an even bigger effect, identified from votes within a narrow margin. Last, to see whether the relevant factor is whether a vote was accepted or rejected, or increased support of the population more generally, I conduct a placebo test which takes all the votes which were narrowly rejected (between 40 and 50 percent) and code "Vote Accepted" as 1 if approval was between 45 and 50 percent. This "placebo vote accepted" shows no relationship with the survey bias at all. This evidence suggests that what matters for the bias is whether the vote was accepted or not. Possible explanations for this result could be citizens' desire to be conform with the majority view, or being on the winning-side.

Especially in light of the results in column (7) (here, due to voting day fixed effects, the effect is identified from a constant respondent sample), it is hard to imagine that the conformity (or winning) bias is entirely due to people strategically not responding ("no"-voters not responding if the vote was accepted or vice versa). Nevertheless, I can analyze individuals' responses to investigate this issue further. Remember that an individual is asked to respond for all votes that were held on a given day, giving rise to multiple observations per individual. If citizens lie, I would expect the same individual to report a "yes" with higher probability if the vote was accepted. Table 5 investigates this issue, where the unit of interest is now the individual. First column regresses a dummy yes (taking a value of 1 if the individual voted "yes", and 0 otherwise) on the dummy vote-passed and individual fixed effects. Individuals have a 36 percentage point higher probability to say "yes", if the vote was accepted. While consistent with lying, this is no evidence for it. After all, a vote may have been accepted precisely 
because individuals voted yes. Instead, I now restrict my sample to individuals which indicated a favourite party. Furthermore, for each individual, I only analyze votes where their favorite party recommended to vote "no". An individual deviates from the party's recommendation if he states to have voted "yes", and 0 otherwise. The empirical strategy will be to test whether an individual is more likely to deviate from the party's recommendation (which is "no") if the vote was accepted. Columns (2) to (5) regress the Indicator variable Deviation Party on the dummy vote accepted and individual fixed effects. Individual fixed effects capture individual's innate propensity to deviate from their favourite party. Clearly, a deviation is up to 35 percentage points more likely if the vote passed. Column (6) analyzes all individuals together. Again, a deviation is 23 percentage points more likely if the vote passed. Columns (7) and (8) restrict the sample to narrowly accepted and rejected votes and finds a smaller, but qualitatively similar effect. Since the party-recommendation occurred before the vote, but the result is revealed after the vote, it is hard to explain this result by other channels than lying.

— insert Table 5 about here —

The evidence thus far suggests that surveys are biased towards a liberal and majority view. Very likely, part of these biases are generated by survey respondents deliberately falsifying their preferences. Even though falsification of answers in surveys is a severe problem, the problem is less grave if one is interested in analyzing differences in survey responses between groups (i.e. gender, religion) and the degree of mis-representation is the same between groups. The next section sheds light on this issue. 


\section{Canton-Characteristics and Differences between Stated and Offi- cial Approval}

Switzerland offers a rare opportunity to shed some light on whether survey-biases vary across subgroups of people. This is especially relevant for researchers using the Eurobarometer or the World Value Survey to compare political attitudes or values across countries. If survey biases are comparable across countries, this type of study makes perfectly sense. If, however, due to different social norms, different type of people respond and/or lie, such an analysis may be less convincing. There is no way one can asses the accuracy of the measured attitudes across countries (since the "true attitudes" for the population are unobserved). The Swiss data allow at least to compare whether survey accuracy differs for different cultures and religions within a country.

The basis for this analysis are voting results at the canton level (available for every federal vote), which I can compare to the stated share yes votes of residents of a given Canton. ${ }^{14}$ The Swiss Cantons are very diverse, in terms of culture, religion, and economic richness. While the majority of Swiss Cantons are of German language, there are also a couple of French-speaking Cantons and an Italianspeaking Canton (plus one Canton (Graubuenden) which has "Romantsch" as its official language). It is well-known that cultural differences between the German and Non-German speaking Cantons are large. For instance, there is the official term "Roestigraben", which refers to the consistently different voting outcomes between the German and Non-German speaking Cantons. Likewise, the Swiss Cantons are heterogenous with regard to religion. While certain Cantons are predominantly Catholic, others are predominantly Protestant, and others are mixed. Last, Cantons vary with regard to other characteristics such as income, age structure, education, and population size.

These data allow to uncover interesting correlations, but not necessarily causal relationships. However, there are usually no data available to shed light on whether survey biases on reported attitudes

\footnotetext{
${ }^{14}$ The VOX-Survey asks for the respondents' canton of residence.
} 
(in this case for different policies) vary across cultures and religions. Again, the reason is that there is information as given in the surveys, but no comparison group revealing "true preferences". Having this caveat in mind, I analyze correlations between the absolute value of survey bias and various Canton-characteristics, taking Canton-level voting results (from federal votes) between 1987-2000 as the basis of the analysis. Since some smaller Cantons have very few survey respondents, I run weighted regressions, with the number of surveyed voters per Canton and ballot assigned as weights.

As can be seen from Table 6, Cantons with a higher share of Protestants have lower biases on average. However, the significance of this result vanishes once more Canton-controls are added. The strongest partial correlations come from the language area and population size. Non-German speaking Cantons have on average a 2.7 percentage points lower biases, compared to German speaking Cantons. Preferences of citizens in large cities are also more accurately represented in surveys. While the exact mechanism behind this result is beyond the scope of this paper, there is supplementary evidence that social norms and the pressure to act accordingly is lower in large cities compared to small-knit communities (Funk, 2010). It is therefore possible that citizens used to express their opinions freely and used to act in an environment of low social pressure also have less problems in revealing their true preferences in surveys.

— insert Table 6 about here —

\section{Conclusion}

This paper analyses how accurately political preferences are represented in surveys. Using unique data on all Swiss votes between 1987-2007, I find that the average difference between stated and real approval is 4.7 percentage point, or 9 percent evaluated at the mean approval. I find large differences 
with regard to policy areas. For instance, citizens inaccurately reveal their preferences (either by nonresponding or deliberate falsification) on issues related to integration, immigration, the environment, and certain types of regulation, but not on federal finances, health, and institutions. Therefore, the paper sheds light on which types of survey questions are more or less likely to be contaminated. Moreover, researchers are often interested in comparing survey answers across different groups. In this case, the relevant question is whether the survey biases are similar across groups. For the predominant religions in Switzerland (Catholicism and Protestantism), the differences in the survey-biases become insignificant, once other factors are controlled for. However, cultural differences in survey accuracy persist and call for caution when comparing survey responses across cultures. 


\section{References}

[1] Alesina, Alberto and Fuchs-Schuendeln, Nicola (2007). Good Bye Lenin (or not?) - The Effect of Communism on People's Preferences. American Economic Review, 97: 1507-1528.

[2] Baretto, Matt A., Guerra, Fernando, Marks, Mara, Nuno, Stephen A. and Woods, Nathan D. (2006). Controversies in Exit Polling: Implementing a Racially Stratified Homogenous Precinct Approach. PS: Political Science \& Politics, 39: 477-483.

[3] Benabou, Roland and Tirole, Jean (2006). Incentives and Pro-Social Behavior. American Economic Review, 96(5): 1652-1678.

[4] Berinsky, Adam (1999). The Two Faces of Public Opinion. American Journal of Political Science, 43(4): 1209-1230.

[5] Berinsky, Adam (2004). Silent Voices. Public Opinion and Political Participation in America. Princeton University Press.

[6] Bernheim, Douglas (1994). A Theory of Conformity. Journal of Political Economy, 102: 841877.

[7] Bertrand, Marianne and Mullainathan, Sendhil (2001). Do people mean what they say? Implications for subjective survey data. American Economic Review, Papers and Proceedings.

[8] Besley, Tim and Coate, Stephen (2008). Issue unbundling via Citizens' Initiatives, Quarterly Journal of Political Science, 3(4): 379-97.

[9] Blumenthal, Mark (2004). Why and How Pollsters Weight. www.mysterypollster.com/

[10] Buetler, Monika, and Marechal, Michel Andre (2007). Framing Effects in Political Decision Making: Evidence From a Natural Voting Experiment, Mimeo. 
[11] Dellavigna, Stefano, List, John A. and Malmendier, Ulrike (2011). Testing for Altruism and Social Pressure in Charitable Giving. Forthcoming: Quarterly Journal of Economics.

[12] Fong, Christina (2001). Social preferences, self-interest, and the demand for redistribution. Journal of Public Economics, 82: 225-246.

[13] Funk, Patricia (2010). Social Incentives and Voter turnout: Evidence from the Swiss Mail Ballot System. Journal of the European Economic Association.

[14] Gerber, Alan S., Green, Donald P., and Larimer, Christopher W. (2008), Social Pressure and Voter Turnout: Evidence from a Large-Scale Field Experiment. American Political Science Review, 102(1): 33-48.

[15] Gneezy, Uri (2005). Deception: the role of consequences. American Economic Review 95, 384394.

[16] Guiso, Luigi, Sapienza, Paola and Zingales, Luigi (2003). People's opimum? Religion and economic attitudes. Journal of Monetary Economics, 50: 225-282.

[17] Holbrook, Allyson L., Krosnick, Jon A., and Pfent, Alison (2007). Response rates in surveys by the news media and government contractor survey research firms. In J. Lepkowski, B. Harris-Kojetin, P. J. Lavrakas, C. Tucker, E. de Leeuw, M. Link, M. Brick, L. Japec, R. Sangster (Eds.), Advances in Telephone Survey Methodology. New York: Wiley.

[18] Holbrook, Allyson L. and Krosnick, Jon A. (2010). Social Desirability Bias in Voter Turnout Reports. Tests Using the Item Count Technique. Public Opinion Quarterly, 74(1): 37-67.

[19] Hopkins, Daniel J. (2009). No More Wilder Effect, Never a Whitman Effect: When and Why Polls Mislead about Black and Female Candidates. The Journal of Politics, 71(3): 769-781. 
[20] Karp, Jeffrey A. and Brockington, D. (2005). Social Desirability and Response Validity: A Comparative Analysis of Overreporting Voter Turnout in Five Countries. The Journal of Politics, $67(3): 825-840$.

[21] Kuran, Timur (1995). Private Truths, Public Lies. The Social Consequences of Preference Falsification. Harvard University Press.

[22] Levy, Paul S. and Lemeshow, Stanley (1999). Sampling of Populations: Methods and Applications. John Wiley and Sons Inc., New York.

[23] Loury, Glenn (1994). Self-Censorship in Public Discourse: A Theory of "Political Correctness" and Related Phenomena. Rationality and Society, 428-461.

[24] Lundquist, Tobias, Ellingsen, Tore and Johannesson, Magnus. (2009). The Aversion to Lying. Journal of Economic Behavior and Organization 70, 81-92, 2009.

[25] Mas, Alexandre and Moretti, Enrico (2009). Peers at Work. American Economic Review, $99(1)$, p. $112-45$.

[26] Morris, Stephen, (2001). Political Correctness. Journal of Political Economy 109, 231-265.

[27] Stromberg, David, (2009). How large is the Bradley effect and does it matter for Obama, mimeo.

[28] Tadelis, Steve, (2011). The Power of Shame and the Rationality of Trust. Haas School of Business Working Paper.

[29] Verba, Sidney, Kay Lehman Schlozman, and Henry E. Brady, (1995). Voice and Equality: Civic Voluntarism in American Politics. Cambridge: Harvard University Press. 


\section{A Appendix: Description of the Votes, by Policy Area}

\section{Agriculture (AGRI):}

1. Initiative against Animal Farms (1989): 371

Goal Initiative: To restrict federal subsidies to agricultural farms that employ family members and cover the animals food by their own production.

2. Against Subsidies for Corn Production (1994): 541

Goal Federal Resolution: Abolish subsidies for Swiss corn.

3. Counterproposal to the Initiative "for an ecological and effective agriculture" (1995): 561

Goal Federal Resolution: create legal framework for an ecological and dynamic agriculture. Introduce direct compensations to farmers for ecological farming and cultivating the countryside.

4. Resolution on Dairy Farming (1995): 562

Goal Federal Resolution: Bring more flexibility of the system of milk quota by allowing farmers to trade.

5. Law on Farming (1995): 563

Goal Federal Law: Regulate payments among farmers for actions (e.g. advertisement) that benefits the whole agricultural sector.

6. Counterproposal to the Initiative "for a natural agriculture" (1996): 591

Goal Federal Resolution: Define the functions and duties of agricultural farmers in the constitution.

7. Initiative "for cheap aliments and ecological agriculture" (1998): 642

Goal Initiative: Abolish all regulations in the agricultural market, and use instead direct compensations for farmers.

8. Federal Resolution on a new Corn Article (1998): 652

Goal Federal Resolution: Liberalization of the market for corn, which was traditionally heavily regulated to guarantee enough corn in cases of wars and crises.

Age Insurance (AI):

1. Initiative for decreasing the retirement age (1988): 352

Goal Initiative: Decrease the retirement age for men from 65 to 62 , and for women from 62 to 60 .

2. Measures for Protecting the Social Insurances (1993): 513

Goal Federal Resolution: Giving the parliament the competence to increase the VAT by 1 percentage point, in order to have more funding for the age insurance.

3. Law on Age Insurance (1995): 571

Goal Federal Law: Equal treatment of women and men. Separate payments for husbands and wives, and stepwise increase of womens retirement age to 64 .

4. Initiative for better age insurance (1995): 572

Goal Initiative: Higher payments for retired people, retirement age 62 for all.

5. Initiative "10th Revision of the Age Insurance without increasing the retirement age" (1998): 643

Goal Initiative: Nullify the planned increase in women's retirement age to 64 .

6. Initiative "for a flexible Age Insurance": 721, "for a flexible Retirement Age" (2000): 722

Goal Initiatives: Allow a flexible retirement age from 62 years onwards for women and men. No reduction in benefits.

7. Initiative "for a secure Age Insurance" (2001): 752

Goal Initiative: Enact higher taxation on energy to finance the Swiss age insurance system. 
8. Federal Resolution on Financing the Age Insurance trough higher taxes (2004): 842

Goal Federal Resolution: Increase VAT with an amount of 0.8 percentage points to have more funding for the age insurance.

9. Initiative Profits of the Swiss National Bank into the Age Insurance (2006): 911

Goal Initiative: Use the profits from the Swiss National Bank to cover the age insurance (apart from 1 billion Swiss Franks that is meant to go to the Cantons).

10. Law on Age Insurance (2004): 841

Goal Federal Law: Guarantee the financing of the age insurance through the following measures: increasing the retirement age for women to 65 , adapting the rents to inflation every 3 instead of 2 years, and increasing the VAT. The referendum was seized because the ballot affects women more than men, and because of the planned increase of the VAT.

\section{Education (EDU):}

1. Initiative for sufficient occupational training (2003): 824

Goal Initiative: Give each individual a constitutional right to have an apprenticeship opportunity.

\section{Environment (ENV):}

1. Train 2000 (1987): 341

Goal Federal Resolution: Enlarge the Swiss railway network. The referendum was seized because of the financial means necessary, and the losses in nature where the railway is planned to be constructed.

2. For Protection of the Swiss Moors (1987): 343

Goal Initiative: Prohibit building constructions in moor sceneries such as the planned shooting range in the Rothenturm moor area.

3. Federal Resolution on the Energy Article (1990): 403

Goal Federal Resolution: Generate a constitutional article that sets guidelines in energy policy. It obliges the government and the cantons to guarantee sufficient supply of energy whilst creating incentives for an economic use.

4. Initiative for Promoting Public Transportation (1991): 412

Goal Initiative: Make the promotion of public transportation a constitutional duty of the federal government. Increase the infrastructure and levy higher fuel taxes.

5. Law on Protection of Waters (1992): 442

Goal Federal Law: To protect the rivers and lakes by putting limits on the amount of waters that can be taken. The Swiss energy producers seized the referendum because they feared not to have enough water for their hydropower plants.

6. Initiative for Saving the Waters (1992): 443

Goal Initiative: Enact strict restrictions on water usage.

7. Federal Resolution on Building the Swiss Railway (1992): 461

Goal Federal Resolution: Extend the Swiss railway network build two new tunnels.

8. Law on Customs on Fuel (1993): 481

Goal Federal Law: Increase fuel taxes to extend and improve the national streets.

9. Federal Resolution on Charges of National Streets (1994): 521

Goal Federal Resolution: Increase the charges for users of the Swiss highways from 30 to 40 Sfr. The increase was meant to correct for inflation over the last years.

10. Federal Resolution on Traffic Road Charges (1994): 522

Goal Federal Resolution: Keep levying a tax on heavy traffic and adjust it to inflation. 
11. Federal Resolution on usage-dependent Traffic Road Charges (1994): 523

Goal Federal Resolution: Gradually make the tax on heavy traffic usage dependent.

12. Initiative for Protection of the Alps (1994): 524

Goal Initiative: Divert all transit traffic on railway within a time span of ten years.

13. Federal Resolution on Funds for the Infrastructure on Public Traffic (1998): 651

Goal Federal Resolution: Use federal funds of 1.5 billion Swiss franks per year to improve the infrastructure of the Swiss railway system.

14. Law on user-dependent heavy Traffic Charge (1998): 641

Goal Federal Law: Enact a user-dependent heavy traffic charge to give incentives to use the railway instead of the streets.

15. For a Pigouvian Tax on Energy (2000): 713

Goal Federal Resolution: Give the constitutional permission for enacting a Pigouvian tax on energy, that is fully re-distributed to the citizens.

16. Initiative for Promoting Solar Energy (2000): 711

Goal Initiative: Enact a charge on non-renewable energies for 25 years, with the charge steadily increasing over time.

17. Initiative "for cutting motorized Road Traffic into Half" (2000): 695

Goal Initiative: Reduce the motorized traffic on the roads into half, within a time span of 10 years.

18. Federal Resolution "For promoting renewable Energies" (2000): 712

Goal Federal Resolution: Create a charge on renewable energies for maximal 15 years (which is lower than the one proposed by the solar initiative).

19. For a car-free Sunday per quarter (2003): 815

Goal Initiative: Define one Sunday per quarter, where no private cars are allowed.

EU:

1. Federal Resolution on the European Economic Area, (1992): 471

Goal Federal Resolution: Guarantee free movement of goods, labor, services and capital between Switzerland and 18 countries of the European Economic Area.

2. Initiative "Direct Democracy for Negotiations with the EU", (1997): 611

Goal Initiative: Have a vote on whether the federal council should be allowed to start negotiating about the Swiss joining the EU.

3. Federal Resolution on Bilateral Agreements between Switzerland and the EU, 1 (2000): 701

Goal Federal Resolution: Enact various bilateral agreements between Switzerland and the European Union. The referendum was seized because of the fear of massive immigration to Switzerland.

4. Initiative "Initiative Yes to Europe!", (2001): 731

Goal Initiative: Force the federal council to start negotiating the terms about Switzerland joining the EU.

5. Federal Resolution on Bilateral Agreements between Switzerland and the EU, 2 (2005): 871

Goal Federal Resolution: Switzerland to take part on the bilateral agreement "Schengen", which facilitates entry between EU countries, and fosters collaboration in Asylum and Visa matters. The referendum was seized because of the fear that abolition of boarder controls increases crime.

6. Federal Resolution on freedom of movement of new EU member States (2005): 881

Goal Federal Resolution: Work towards the free movement between Swiss and residents of new EU member States. The referendum as seized because of the fear of a large inflow of foreigners, and increase in unemployment, and harsher competition on the labor market for the Swiss. 
7. Law on Cooperation with Eastern Europe (2006): 921

Goal Federal Law: Give financial aid to formerly communist countries to help them develop. The referendum was seized because of the financial consequences for the federal budget.

\section{Finances (FIN):}

1. Initiative: "Excessive Gold Reserves for the age insurance (2002): 781

Goal Initiative: Use supplementary gold reserves from the Swiss National Bank to cover the deficit in the Age Insurance (AHV).

2. Federal Resolution on Reorganizing the Federal Finances (1991): 421

Goal Federal Resolution: Convert the old Sales Tax into a VAT and allow an increase in taxes to finance the age insurance.

3. Federal Resolution on Federal Finances (1993): 511

Goal Federal Resolution: Convert the old Sales Tax into a VAT.

4. Federal Resolution for Healthy Federal Finances (1993): 512

Goal Federal Resolution: Increase tax rate by 0.3 percentage point, if change to the VAT accepted.

5. Federal Resolution on Consumption Taxes (1993): 514

Goal Federal Resolution: Concert customs duty of cars and petroleum into consumption taxes.

6. Law on Reducing Federal Expenses (1995): 564

Goal Federal Resolution: Make it harder to pass federal laws with significant expenses: the majority of all parliamentary members is needed, and not only the voting parliamentary members.

7. Federal Resolution on Measures for Budget Balancing (1998): 632

Goal Federal Resolution: Give guidelines to the federal council and the parliament to reduce the Swiss deficit.

8. Federal Resolution promoting a Debt Break (2001): 751

Goal Federal Resolution: Make a binding rule in the constitution that ties federal spending to federal revenues.

9. Counterproposal Initiative "Excessive Gold Reserves for AHV" (2002): 782

Goal Counterproposal: Keep the money from the Swiss gold reserves, but distribute the interests as follows: $1 / 3$ to finance the age insurance, $1 / 3$ for the cantons, and $1 / 3$ to a solidarity fund for people in need.

10. Federal Resolution on the Swiss Financial Regime (2004): 862

Goal Federal Resolution: Renew the federal competence to tax income and to enact a VAT.

\section{Foreign (FOR):}

1. Federal Resolution on Switzerland joining the Bretton Woods (1992): 441

Goal Federal Resolution: To join the Bretton Woods Institutions. The referendum was seized with the argument of the ineffectiveness of these institutions and the payment of a fee.

2. Law on Military Forces with Peaceful Missions (1994): 531

Goal Federal Resolution: The federal level should receive the competence to send Swiss military people to UN operations with peaceful missions. The referendum was seized with the argument that this federal resolution contrasts the Swiss no-vote on joining the UN.

3. Initiative for joining the United Nations (2002): 761

Goal Initiative: Swiss should join the United Nations. 


\section{Health (HEALTH):}

1. Law on Health Insurance (1994): 551

Goal Federal Law: Stop the increasing costs of health premia by allowing for increasing competition between insurances and health suppliers. Include some new services (e.g. elderly care at home) in the mandatory insurance, and subsidize poor people's premia. The referendum was seized because of subsidies, which increase government spending.

2. Law on Insurance of Disabled (1999): 684

Goal Federal Law: Take measures to stop the deficit in the disability insurance. Increase the VAT tax on 1 percentage point, and take measures to save costs. The referendum was taken because the cost-saving measures included reducing some part of the benefits.

3. Law on Health Insurance (1987): 342

Goal Federal Law: Take measures to stop the continuing explosion of costs in the health sector, and grant better conditions for working women who give birth to a child.

4. Initiative for a cheap (better: financially secured) Health Insurance (1992): 431

Goal Initiative: Increase the federal subsidies for health insurance premia.

5. Initiative for Reducing Problems with Alcohol (1993): 515

Goal Initiative: Prohibit advertisement of products containing Alcohol.

6. Initiative for Reducing Problems with Tabacco (1993): 516

Goal Initiative: Prohibit advertisement of Tobacco products.

7. Initiative for a healthy Health Insurance (1994): 552

Goal Initiative: Make health premia dependent on income, and thereby increase the solidarity between rich and poor.

8. Initiative "Youth Without Drugs" (1997): 621

Goal Initiative: Prescribe a federal policy that directly aims at abstinence. Prohibit the release of narcotic substances.

9. Initiative "for a reasonable drug policy" (1998): 653

Goal Initiative: Exempt the consume of drugs from punishment.

10. Federal Resolution on Medical Prescription for Heroine (1999): 683

Goal Federal Resolution: Create the legal base for the continuation of medical prescription of Heroine for heavy drug addicts. The referendum was seized because of the costs involved with the program.

11. Law on the Insurance of Mothers (1999): 685

Goal Federal Law: Improve conditions for working women. Guarantee $80 \%$ of the salary for the first 12 months after giving birth. The referendum was seized because of the costs associated with the insurance for working mothers.

12. Law Regulating Abortion (2002): 771

Goal Federal Law: Legalize abortion within the first twelve weeks of pregnancy, if the women is in need.

13. Initiative "Protection of Mother and Baby" (2002): 772

Goal Initiative: Legalize abortion within the first twelve weeks of pregnancy only if the mothers life is in danger.

14. Initiative "For reasonable Health Costs" (2003): 814

Goal Initiative: Increase subsidies of health care premia by increasing the VAT, and make newly health premia dependent on income.

15. Initiative "Equal Rights for Disables" (2003): 821

Goal Initiative: Give disabled people the right have convenient access to building with public interest. 
16. Initiative "For a social Health Insurance" (2007): 931

Goal Initiative: Create one single mandatory health insurance, and make the health premia dependent on income.

\section{Immigration (IMM):}

1. For restricting immigration (1988): 363

Goal Initiative: Restrict the share of immigrants to $2 / 3$ of foreigners leaving the country, as long as the Swiss population exceeds 6.2 million people.

2. For easier naturalization of Immigrants (1994): 533

Goal Initiative: Regulate and facilitate the naturalization of immigrants.

3. Initiative against Illegal Migration (1996): 601

Goal Initiative: Make the procedure of seeking political asylum in Switzerland less attractive.

4. Initiative for Restricting Immigration (2000): 714

Goal Initiative: Reduce the share of foreigners to 18 percent of the Swiss population.

5. Initiative against Misuse in Asylum Matters (2002): 791

Goal Initiative: The initiative requires to directly reject petitions for asylum if the asylum seeker is in a safe country.

6. For easier Naturalization of Immigrants of 2 Generation (2004): 851

Goal Federal Resolution: Facilitate the Naturalization of Immigrants of 2 Generation.

7. Federal Resolution on Naturalization of Immigrants of 3 Generation (2004): 852

Goal Federal Resolution: Change the constitution so that immigrant children of the 3 generation automatically receive Swiss citizenship at birth.

8. Law on Foreigners (2006): 912

Goal Federal Law: Facilitate the integration of highly qualified foreigners coming from outside the EU. The referendum was seized because of apparent discrimination for low-skilled workers outside the EU.

9. Change of the Asylum Law (2006): 913

Goal Federal Law: Decrease misuse by facilitating means of rejection of asylum seekers who refuse to reveal their identity. Also, reduction of federal aid for people, who did not get granted asylum. The referendum was seized because the law was found to be inhuman.

10. Asylum Law (1987): 321

Goal Federal Law: Procedural Changes in the Asylum Law that facilitate and fasten the judgment of the increasing amount of asylum seekers.

11. Law on Residence on Foreigners (1987): 322

Goal Federal Law: Procedural Changes in the Law on Residence on Foreigners that facilitate and fasten the judgment of the increasing amount of asylum seekers.

12. Law on Mandatory Measures in Immigration Law (1994): 553

Goal Federal Law: Take measures to facilitate expulsion of rejected asylum seekers.

13. Asylum Law (1999): 681; Federal Resolution on Urgent Matters in the Area of Asylum (1999): 682

Goal Ballots: Take measures against abuse in the area of asylum seeking. For instance: Do not grant the same rights to asylum seekers who hide their identity or apply after having resided illegally in Switzerland.

\section{Institutions (INST)}

1. Law on Procedures on Initiatives with Alternative Drafts (1987): 324

Goal Federal Resolution: Allow for two yes-votes if there is an initiative as well as a counter-proposal to vote on. 
2. For reducing the voting age from 21 to 18 (1991): 411

Goal Federal Resolution: Decrease the voting age from 21 to 18.

3. Federal Resolution on a new Federal Constitution (1999): 671

Goal Federal Resolution: Revise the federal constitution with regard to harmonization and modernization.

4. Initiative for Faster Direct Democracy (2000): 692

Goal Initiative: The initiative asks for a vote no later than 12 month after the initiative has been submitted.

5. Initiative for Direct Democracy in Military Expenses (1987): 323

Goal Initiative: Create the possibility to seize the referendum for military expenses.

6. Federal Resolution on the Eligibility in the Federal Council (1999): 661

Goal Federal Resolution: Abolish the strict rule than no more than one council member can come from the same Canton.

7. Federal Resolution on the Reform of the Judiciary (2000): 691

Goal Initiative: Harmonize the cantonal laws on procedure on civil and criminal suits. To bring relief to the federal courts, courts of lower instances should be created.

8. Initiative "More rights for the people thanks to the Referendum with Counter Proposal" (2000): 715

Goal Initiative: Extend citizens rights by creating a new institution - called the constructive referendum. The constructive referendum gives citizens the possibility to propose a counter-proposal to certain passages of federal laws, if 50’000 citizens sign.

9. Federal Resolution on Changes of Citizens' Rights (2003): 801

Goal Initiative: Extend citizensrights by creating the possibility of initiatives for laws at the federal level.

Military (MIL):

1. Federal Resolution for a Civilian Service for Military Deniars (1992): 445

Goal Federal Resolution: To offer civil service instead of prison for people who refuse to go to the military.

2. Initiative for a Switzerland without Army (1989): 382

Goal Initiative: Complete Abolishment of the Swiss Army

3. Swiss Military Law (1991): 422

Goal Federal Resolution: Revise criminal code such that military denial is no longer punishable by prison, but instead by community service.

4. Initiative "No more than 40 places for Arms" (1993): 491

Goal Initiative: Prohibit the new construction of places for arms.

5. Initiative "For a Switzerland without new Fighter Jets" (1993): 492

Goal Initiative: Prohibits buying new fighter jets until the year of 2000.

6. Initiative "Against Exporting Arms" (1997): 612

Goal Initiative: Prohibit the export and passing of any arms and munitions.

7. Against Federal Regulations on Gun Powder (1997): 613

Goal Federal Resolution: Abolish the federal monopoly to fabricate and sell gun powder.

8. Initiative Federal Law on the Army (2001): 741

Goal Federal Law: Revise the military law such that Swiss military corps in peaceful operations have the right to arm themselves if necessary.

9. Federal Law on the Army (Cooperation in Education) (2001): 742

Goal Federal Resolution: Give the federal government the right to negotiate international agreements for cooperation in military education. 
10. Initiative "for a Switzerland without Army" (2001): 753

Goal Initiative: Abolish the Swiss Army.

11. Initiative "for a voluntary civil service" (2001): 754

Goal Initiative: create a civil service for peaceful missions in and outside of Switzerland, on a voluntary basis.

12. Initiative "saving the military" (2002): 723

Goal Initiative: cut federal expenses for the military within 10 years, to half of the level of military expenses in 1987.

13. Federal Law on the Military (2003): 811

Goal Federal Resolution: Change the military law as follows: Release the Swiss men earlier from their military duty, but increase the duration of the military education. The total weeks spent in military service are reduced. The referendum was seized with the argument that the new army would not be capable of defending Switzerland.

Nuclear Energy (NUC):

1. Initiative against Powerplants (1990): 402

Goal Initiative: Prohibit building new nuclear powerplants for 10 years.

2. Initiative against Nuclear Energy (1990): 401

Goal Initiative: Shut down all current nuclear powerplants and forbid building any new ones.

3. Initiative "Against Nuclear Power Plants" (Strom ohne Atom) (2003): 822

Goal Initiative: Shut down step-by-step the current five nuclear power plants from Switzerland.

4. Initiative "For Restricting Nuclear Risks" (2003): 823

Goal Initiative: Prohibits building new nuclear powerplants for the next ten years.

\section{Redistribution (REDIST):}

1. Measures on Unemployment Insurance (1993): 505

Goal Federal Resolution: Increase the number of eligible days from 300 to 400, but reduce the amount of the last income from 80 to 70 percent. The referendum was seized because of the reduction of the money from 80 to 70 percent.

2. Federal Resolution on further Increases in Health Insurance Premias (1993): 504

Goal Federal Resolution: Regulation of Health Insurance Premias. The referenda was seized because the federal resolution wanted a minimal cost-sharing from the patients of 10 Sfr. per hospital day. This minimal cost-sharing was perceived as asocial.

3. For lower costs of hospitals (2000): 724

Goal Initiative: To reduce the services included in the mandatory health insurance to hospital costs. Through this measure, the rising costs of the health insurance premia are supposed to be decelerated.

4. Initiative for low Pharmaceutical Prices (2001): 732

Goal Initiative: The goal of the initiative is to only re-imburse the consumer with the health insurance, if he used the cheapest medicament. Through this measure, the rising costs of the health insurance premia are supposed to be decelerated.

5. Federal Resolution on Taxation of Families, Properties and Stamp Duties (2004): 843

Goal Federal Law: The goal of the ballot is to change tax law to eliminate the disadvantage of married couples. The tax law was also revised to give incentive to own property. The referendum was seized because of the last point, which supposedly favors the rich. 
6. Initiative Postal Services for all (2004): 853

Goal Initiative: To force the government to guarantee a broad supply of postal services. If necessary, services are covered by federal funds.

7. Federal Resolution on Financing the Unemployment Insurance (1997): 622

Goal Federal Resolution: Decrease the payments to the unemployed by 1-3 percentage to help stopping the growing deficit in the unemployment insurance.

8. Initiative "Proprietary for Everybody" (1999): 662

Goal Initiative: Provide tax incentives to encourage buying property.

9. Federal Law on the Unemployment Insurance (2002): 792

Goal Federal Law: Ensure the financing of the unemployment insurance through various measures: subsidies by Cantons and the federal government, shorter period during which unemployment benefits can be received. The referendum was seized because of the latter change.

10. Initiative "Yes to Fair Rental Prices" (2003): 813

Goal Initiative: Tie the rental prices to the interest rates for mortgages - in cases of increasing as well as decreasing interest rates. The parliament and the federal council recommended voting no to this initiative, because they work on a revision of the law that wants to tie rental prices to inflation instead of interest rates for mortgages.

\section{Regulation (REG):}

1. Federal Resolution on Building Vines (1990): 395

Goal Federal Resolution: Continue existing Regulatory Measures such as import quota and add new ones to enhance the quality of wines (e.g. defining different classes of quality). The referenda was seized because of the ongoing existence of import quota, which gives rise to economic rents to importers and increases wine prices in Switzerland.

2. Change Swiss Criminal Code/ Swiss Military Code (1992): 446

Goal Federal Law: Modernize the laws concerning sexual matters. Strict Prohibition of hard Pornography, and rape within married couples newly a criminal act. The Referendum was seized because of the quasilegalization of soft pornography, and the more lenient regulation of sexual acts between young people of similar age.

3. Law on Paysants' Land Rights (1992): 466

Goal Federal Law: Regulates and ensures access to land for agriculture. The referendum was seized because of a general opposition against regulatory measures in agriculture.

4. Federal Resolution on the Union of the community Laufen with the Canton BS (1993): 502

Goal Federal Resolution: Enable the District Laufen to join the Canton BS.

5. Federal Resolution on Abolishing Permissions to build Dioceses (2001): 743

Goal Federal Resolution: Delete a paragraph in the constitution that regulates catholic churches with dioceses.

6. Initiative for lower working hours (2002): 762

Goal Initiative: Reduce the average regular working load from 40 to 36 hours.

7. Law on the Electricity Market (2002): 783

Goal Federal Law: Deregulate the Electricity Market by letting consumers choose their supplier. The referendum was seized with the argument that a free electricity market threatens the quality of the services.

8. Change of Swiss Code of Obligations (2004): 832

Goal Federal Counter Proposal: Modernize the tenancy law. Tie the rents to inflation and set up new criteria ("comparable rents") for judging abusive rental prices. The referendum was seized because of a fear of increasing rental prices. 
9. Change Compensation Law (2004): 854

Goal Federal Law: Improve the conditions for working women after giving birth to a child. The referendum was seized by the right-wing party SVP, because it would cause an increase in government spending.

10. Law on Homosexual Couples (2005): 872

Goal Federal Law: Create the possibility for homosexual couples to have similar legal rights as married heterosexual couples. The referendum was seized because of an apparent threat to the family.

11. Initiative for food without Gen-Technology (2005): 891

Goal Initiative: Prohibit the use of gen-technologically modified plants and animals in the Swiss agriculture for 5 years.

12. Law on the Organization of the Federal Judicature (1990): 396

Goal Federal Law: The goal of the initiative was to bring relief to the federal judiciary, which suffered from a high number of cases and too little personal. The referendum was seized because of two changes: the increase of the amount in dispute necessary for a case to go to a federal judiciary, and the increased power of federal judges to check for the relevance of the cases to be eligible for a federal dispute. The fear was an undermining of the Swiss legal system.

13. Initiative against Speculation with Properties (1988): 361

Goal Initiative: Prohibit buying land with the purpose of investment. Land should be assigned to people who use it for living, working, or farming.

14. Initiative for Shorter Working Hours (1988): 362

Goal Initiative: Restrict the maximal legal working hours to 40 hours per week.

15. Initiative for Restricting Animal Testing (1992): 432

Goal Initiative: Prohibit animal testing by law.

16. Counterproposal to the Initiative "Against Misuse in Gentechnology" (1992): 444

Goal Initiative: Put guidelines in the constitution to regulate and avoid misuse of Gen-Technology.

17. Swiss Criminal Code on Military Law (1994): 542

Goal Federal Resolution: Revise criminal code and military law such that racist acts are treated as criminal offenses.

18. Law on Acquisition of Property through Foreigners (1995): 573

Goal Federal Resolution: Change the law in order to facilitate possession of Swiss property by foreigners.

19. Federal Resolution on the Revision of the Language Article (1996): 581

Goal Federal Resolution: Put new paragraphs in the federal constitution that support the diversity of languages in Switzerland.

20. Federal Resolution on the union of the community Vellerat with the Canton JU (1996): 582

Goal Federal Resolution: Allow the bernese community Vellerat to join the Canton Jura.

21. Against the Federal Duty to buy Spirits (1996): 584

Goal Federal Resolution: Release the federal government from the obligation to buy Swiss spirits.

22. Federal Law regulating working conditions (1998): 654

Goal Federal Resolution: Revise the law to allow for more flexible regulations concerning working hours. At the same time, guarantee better protection and compensation of night shifts and working women giving birth.

23. Initiative "for Protection against Gen-Manipulation" (1998): 631

Goal Initiative: Prohibit Gen-Manipulation with Animals, and prohibit the release of genetically manipulated organisms. 
24. Initiative "S.o.S. - Schweiz ohne Schnffelpolizei" (1998): 633

Goal Initiative: Restrict the polices' possibilities to gather information on citizens to cases with known criminal offenses.

25. Federal Law regulating working conditions (1998): 654

Goal Federal Resolution: Revise the law to allow for more flexible regulations concerning working hours. At the same time, guarantee better protection and compensation of night shifts and working women giving birth. Compared the the federal resolution (1996), which was rejected by the voters, the measures for protection were expanded.

26. Federal Resolution on Regulating Transplantation Medicine (1999): 664

Goal Federal Resolution: Set the legal framework for transplantation medicine in the constitution.

27. Federal Law on City and Regional Planning (1999): 663

Goal Federal Resolution: Allow for a more flexible use of former agricultural land and buildings.

28. Initiative "for a fair Representation of Women in the Government" (2000): 693

Goal Initiative: Introduce Quota for the federal parliament and the judiciary.

29. Initiative "against Manipulations in the Technology of Reproduction" (2000): 694

Goal Initiative: Restrict the use of artificial insemination.

30. Federal Law on the Employees of the Government (2000): 725

Goal Federal Resolution: Make the conditions for government employees more competitive. Abolish the status as a civil servant, but instead guarantee a good protection against layoffs.

31. Federal Law on Cantonal Contributions to Treatments in Hospitals (2003): 802

Goal Federal Resolution: Revise the federal law on health to regulate Cantons' subsidies for hospital stays of patients with complementary insurances.

32. Federal Law on Civil Protection (2003): 812

Goal Federal Resolution: Coordinate and regulate the different cantonal and communal measures for protecting civilians in case of catastrophe.

33. Initiative "Stricter Regulation for Sexual Offenders" (2004): 833

Goal Initiative: Prescribe Life-Long custody for dangerous sexual offenders who do not respond to treatment.

34. Law on Research on Embryonic Stem Cells (2004): 863

Goal Federal Resolution: Regulate by law the conditions under which research on stem cells can be conducted.

35. Federal Law on Opening Hours of Shops (2005): 892

Goal Federal Resolution: Allow shops in airports and train stations to be open on Sundays.

Traffic (TRAFF):

1. For higher Speed Limits 130/100 (1989): 381

Goal Initiative: increase the speed limit on highways from 120 to 130, and from 80 to 100 on regular roads.

2. Counter Proposal to the Avanti Initiative (2004): 831

Goal Counter Proposal: To extend the road network to guarantee a well functioning and efficient road infrastructure.

3. Initiative for Restricting Road Making (1990): 391

Goal Initiative: Restrict the Swiss road network to the size of 1986. Only allow to build new roads if existing roads are abolished. 
4. Initiative against Freeway between Murten and Yverdon (1990): 392

Goal Initiative: Against building the planned freeway between Murten and Yverdon.

5. Initiative against Freeway in the Knonauer Amt (1990): 393

Goal Initiative: Against building the planned freeway in the Knonauer Amt.

6. Initiative against Freeway between Biel and Solothurn/Zuchwil (1990): 394

Goal Initiative: Against building the planned freeway between Biel and Solothurn/Zuchwil .

7. Law on Road Traffic (1990): 404

Goal Federal Resolution: Change the federal law on road traffic with the goal to guarantee security on the streets. The referendum was seized because of the planned increase of the maximal latitude of cars in accordance with EU standards. The arguments of the opponents was a further increase in truck traffic.

8. Initiative "for a better security on the streets with speed limit 30" (2001): 733

Goal Initiative: Reduce speed limits in town from 50 to $30 \mathrm{~km}$ per hour.

\section{Federalism (FED):}

1. Federal Resolution on Coordination on Traffic Policy (1988): 351

Goal Federal Resolution: Give the competence to the federal government to coordinate traffic policy. Create the possibility of levying road charges to ensure an ecological development of private and public traffic. There was a debate on who should have the responsibility, federal or cantonal level.

2. Federal Resolution in financial compensation between Federal/Cantonal level (2004): 861

Goal Federal Resolution: Re-organize and systematize the share of duties between federal and cantonal level. Furthermore, determine the transfers between rich and poor cantons.

3. Federal Regulation of Misuse of Arms (1993): 501

Goal Federal Resolution: Make regulation of arms a federal instead of a cantonal matter. The main objective is to be able to better control abuse of arms.

4. Law on Aviation (1994): 525

Goal Federal Law: Create legal competence to ask for charges for landing. Regulatory measures on airport security newly federal instead of cantonal authority, against which the referendum was seized.

5. Federal Resolution on the Promotion of Culture (1994): 532

Goal Federal Resolution: To give the authority to foster culture also to the federal level, and not until now, only to the cantonal level.

6. Federal Resolution on the Cantonal Authority on Personal Military Equipment (1996): 583

Goal Federal Resolution: Make the purchasing of military equipment a federal instead of Cantonal authority. Note, the vote was: Would you like to abandon the cantonal authority in military equipment?

7. Federal Resolution on Constitutional Matters on Education (2006): 901

Goal Federal Resolution: Harmonize the Swiss Education system across Cantons. While secondary education continues to be a cantonal matter, the Cantons would be forced to harmonize the starting age, length and degrees.

8. Law on Family Surpluses (2006): 922

Goal Federal Law: To harmonize the different Cantonal regulations on surpluses for families. The referendum was seized because of opposition against a federal interference in cantonal matters. 
FIGURE 1

Distribution Survey Bias ("Share Yes" Survey - "Share Yes" Ballot)

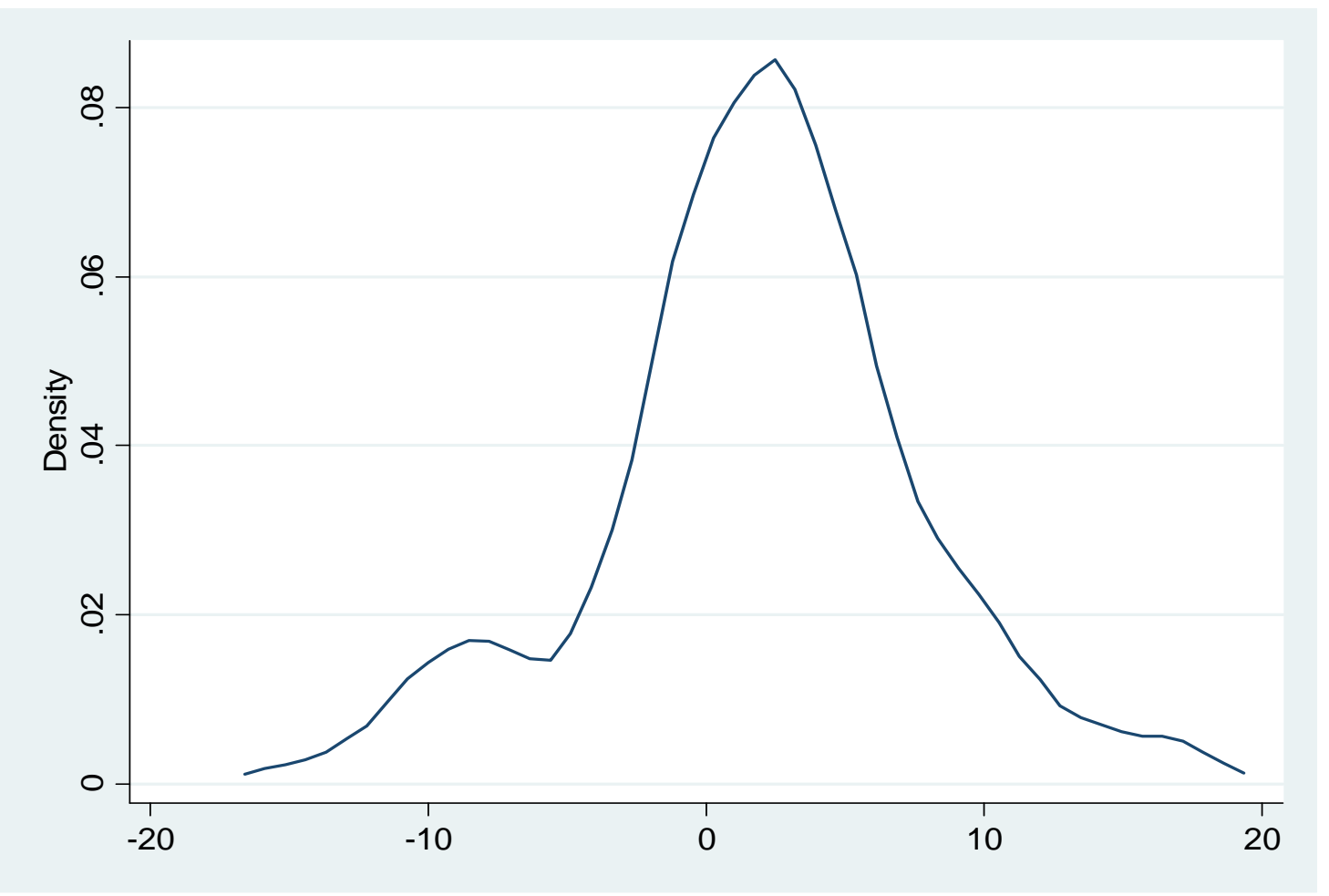

Notes: Figure 1 shows the kernel distribution of the gaps between reported share yes in the VOX survey and and actual share yes at the ballot. Data Source: Swiss Federal Statistical Office; VOXData. 


\section{FIGURE 2}

Distribution Survey Bias, weighted and unweighted samples

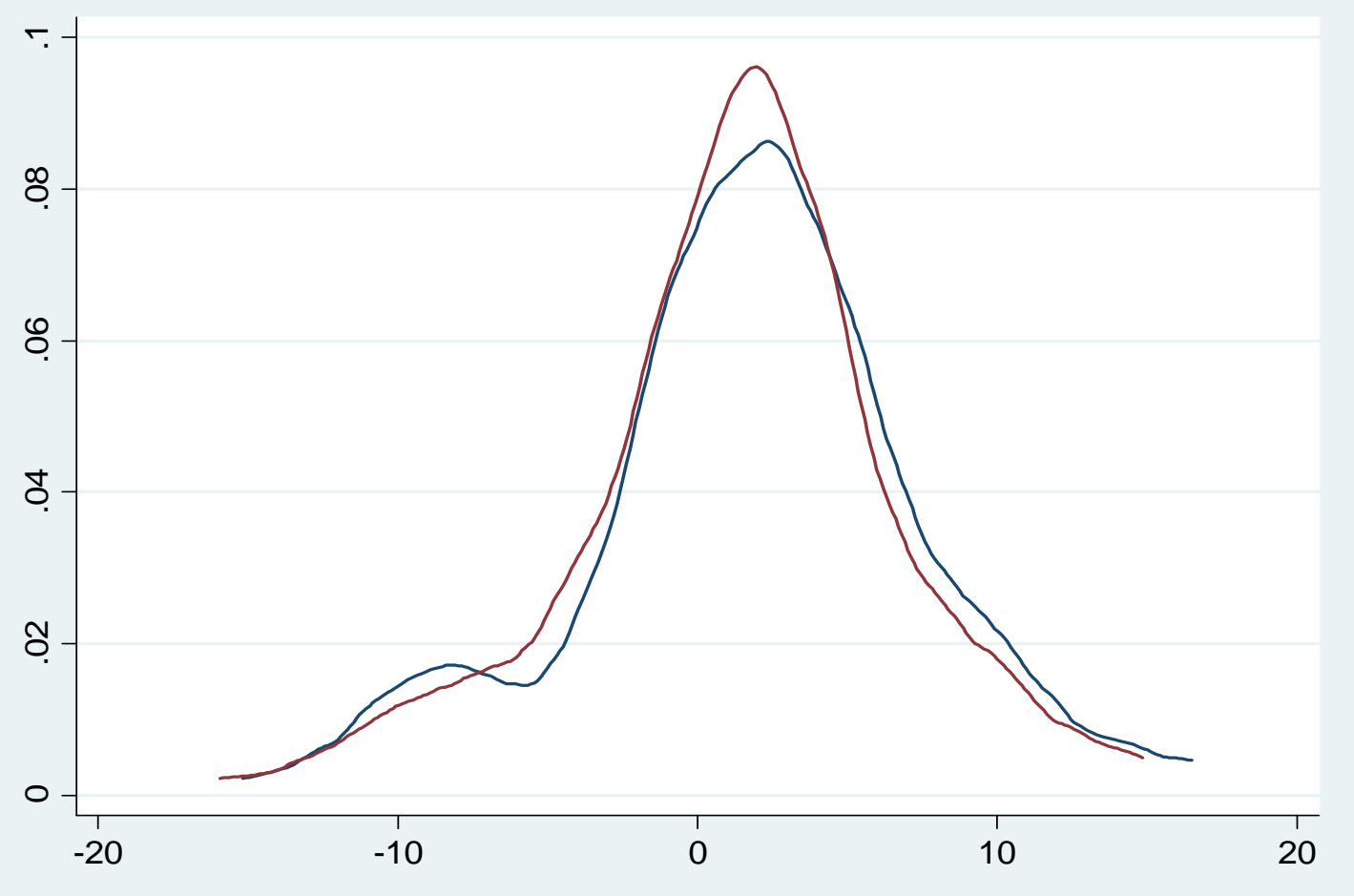

Notes: Figure 2 shows the kernel distributions of the gaps between reported share yes in the VOX survey and and actual share yes at the ballot. The black line uses unweighted data, the red line weighted data. Data Source: Swiss Federal Statistical Office; VOX-Data. 
TABLE 1

Summary Statistics, VOX Sample and Swiss population sample (people older than 20)

\begin{tabular}{|c|c|c|c|c|c|c|}
\hline & $\begin{array}{c}\text { VOX } \\
\text { Mean (1990) } \\
\end{array}$ & $\begin{array}{c}\text { Swiss (PUS Data) } \\
\text { Mean (1990) }\end{array}$ & $\begin{array}{c}\text { Test Diff. in Means } \\
\text { P-Value }\end{array}$ & $\begin{array}{c}\text { VOX } \\
\text { Mean (2000) } \\
\end{array}$ & $\begin{array}{c}\text { Swiss (PUS Data) } \\
\text { Mean (2000) }\end{array}$ & $\begin{array}{c}\text { Test Diff. in Means } \\
\text { P-Value }\end{array}$ \\
\hline Share Women & 0.50 & 0.51 & 0.1117 & 0.51 & 0.52 & 0.9605 \\
\hline Share Protestants & 0.44 & 0.41 & 0.0002 & 0.43 & 0.35 & 0.0000 \\
\hline Share Catholics & 0.47 & 0.46 & 0.4768 & 0.43 & 0.42 & 0.0556 \\
\hline Age 20-39 & 0.41 & 0.42 & 0.7039 & 0.35 & 0.38 & 0.0000 \\
\hline Age 40-59 & 0.35 & 0.33 & 0.2787 & 0.35 & 0.36 & 0.0050 \\
\hline Age 60plus & 0.24 & 0.25 & 0.3030 & 0.30 & 0.26 & 0.0000 \\
\hline Linguistic Area: Geman & 0.72 & 0.72 & 0.8968 & 0.69 & 0.71 & 0.0118 \\
\hline Linguistic Area: French & 0.23 & 0.23 & 0.7538 & 0.24 & 0.24 & 0.4949 \\
\hline Linguistic Area: Italian & 0.05 & 0.05 & 0.8133 & 0.06 & 0.05 & 0.0004 \\
\hline Higher Education & 0.21 & 0.19 & 0.0084 & 0.30 & 0.27 & 0.0000 \\
\hline
\end{tabular}

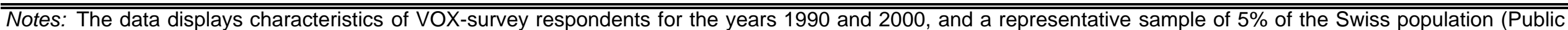

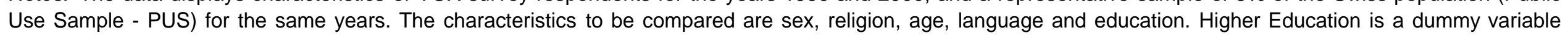
taking a value of 1 if the individual has a high-school degree or higher. Individuals older or equal to 20 years are considered. 
TABLE 2

Survey Bias, by Topic

\begin{tabular}{|c|c|c|c|c|c|}
\hline & (1) & (2) & (3) & (4) & $\begin{array}{c}\text { (5) } \\
\text { Share of votes } \\
\text { supported by Left }\end{array}$ \\
\hline PRO INTERNATIONAL INTEGRATION (9) & $\begin{array}{c}5.646^{\star \star \star} \\
(0.938)\end{array}$ & $\begin{array}{c}3.639 * \star \star \\
(0.899)\end{array}$ & $\begin{array}{c}5.517^{\star \star \star} \\
(0.914)\end{array}$ & $\begin{array}{c}5.459 * \star \star \\
(2.061)\end{array}$ & 100 \\
\hline PRO IMMIGRATION (4) & $\begin{array}{c}6.947 \\
(5.446)\end{array}$ & $\begin{array}{c}5.061 \\
(4.298)\end{array}$ & $\begin{array}{c}8.131 \\
(5.070)\end{array}$ & $\begin{array}{c}7.294 \\
(5.909)\end{array}$ & 75 \\
\hline CONTRA IMMIGRATION (8) & $\begin{array}{c}-5.123^{\star \star \star} \\
(1.867)\end{array}$ & $\begin{array}{c}-3.564^{\star *} \\
(1.703)\end{array}$ & $\begin{array}{c}-2.934 \\
(2.146)\end{array}$ & $\begin{array}{l}-4.103^{*} \\
(2.217)\end{array}$ & 0 \\
\hline CONTRA INCREASE ARMY (10) & $\begin{array}{c}2.946^{\star \star \star} \\
(0.564)\end{array}$ & $\begin{array}{c}2.285^{\star \star \star} \\
(0.618)\end{array}$ & $\begin{array}{l}0.0101 \\
(1.153)\end{array}$ & $\begin{array}{l}4.734^{\star \star} \\
(2.048)\end{array}$ & 86 \\
\hline PRO PROTECTION ENVIRONMENT (23) & $\begin{array}{c}3.747^{\star \star \star} \\
(1.391)\end{array}$ & $\begin{array}{l}3.253^{\star \star} \\
(1.379)\end{array}$ & $\begin{array}{c}4.070^{\star \star \star} \\
(1.400)\end{array}$ & $\begin{array}{c}4.269^{\star} \\
(2.201)\end{array}$ & 100 \\
\hline CONTRA NUCLEAR ENERGY (4) & $\begin{array}{c}5.187^{\star \star \star} \\
(0.738)\end{array}$ & $\begin{array}{c}4.296^{\star \star \star} \\
(1.153)\end{array}$ & $\begin{array}{c}1.377^{\star \star \star} \\
(0.476)\end{array}$ & $\begin{array}{c}6.914^{\star \star \star *} \\
(2.032)\end{array}$ & 100 \\
\hline PRO BUDGET BALANCE (2) & $\begin{array}{c}2.663 \\
(1.653)\end{array}$ & $\begin{array}{c}2.603 \\
(1.634)\end{array}$ & $\begin{array}{l}6.048^{\star \star \star} \\
(1.620)\end{array}$ & $\begin{array}{c}1.982 \\
(3.176)\end{array}$ & 0 \\
\hline PRO DIRECT DEMOCRACY (5) & $\begin{array}{c}2.190 \\
(3.563)\end{array}$ & $\begin{array}{c}1.607 \\
(3.114)\end{array}$ & $\begin{array}{c}2.121 \\
(2.594)\end{array}$ & $\begin{array}{c}4.585 \\
(3.791)\end{array}$ & 60 \\
\hline PRO LIBERALIZATION HEALTH (5) & $\begin{array}{c}0.937 \\
(1.536)\end{array}$ & $\begin{array}{c}0.192 \\
(1.212)\end{array}$ & $\begin{array}{c}0.941 \\
(1.953)\end{array}$ & $\begin{array}{c}2.081 \\
(2.639)\end{array}$ & 100 \\
\hline CONTRA LIBERALIZATION HEALTH (5) & $\begin{array}{l}-0.374 \\
(0.667)\end{array}$ & $\begin{array}{l}-0.744 \\
(1.024)\end{array}$ & $\begin{array}{c}0.851 \\
(1.171)\end{array}$ & $\begin{array}{c}2.619 \\
(2.319)\end{array}$ & 67 \\
\hline PRO REDISTRIBUTION (7) & $\begin{array}{c}3.175^{\star \star \star} \\
(1.076)\end{array}$ & $\begin{array}{l}2.553^{\star \star} \\
(1.267)\end{array}$ & $\begin{array}{c}0.885 \\
(1.423)\end{array}$ & $\begin{array}{l}5.186^{\star \star} \\
(2.100)\end{array}$ & 100 \\
\hline PRO INCREASE RETIREMENT AGE (2) & $\begin{array}{l}-3.436 \\
(2.691)\end{array}$ & $\begin{array}{l}-3.851 \\
(2.794)\end{array}$ & $\begin{array}{c}0.784 \\
(2.738)\end{array}$ & $\begin{array}{l}-3.031 \\
(2.085)\end{array}$ & 50 \\
\hline CONTRA INCREASE RETIREMENT AGE (5) & $\begin{array}{c}0.106 \\
(1.406)\end{array}$ & $\begin{array}{c}0.771 \\
(1.549)\end{array}$ & $\begin{array}{l}-2.745 \\
(2.686)\end{array}$ & $\begin{array}{c}3.564 \\
(2.537)\end{array}$ & 100 \\
\hline PRO GENDER EQUALITY (3) & $\begin{array}{c}6.661 \\
(4.656)\end{array}$ & $\begin{array}{c}5.463 \\
(3.641)\end{array}$ & $\begin{array}{c}5.489 \\
(3.589)\end{array}$ & $\begin{array}{l}7.607^{\star \star *} \\
(3.353)\end{array}$ & 100 \\
\hline PRO LIBERAL ATTITUDES (2) & $\begin{array}{c}8.515^{\star \star \star} \\
(0.779)\end{array}$ & $\begin{array}{c}6.331^{\star \star \star} \\
(0.142)\end{array}$ & $\begin{array}{l}7.911^{\star \star \star} \\
(0.127)\end{array}$ & $\begin{array}{l}7.164^{\star \star \star} \\
(2.211)\end{array}$ & 100 \\
\hline Sample & Unweighted & $\begin{array}{l}\text { Correction } \\
\text { Oversampling } \\
\text { Age, Religion } \\
\text { Education }\end{array}$ & $\begin{array}{c}\text { Correction } \\
\text { Oversampling } \\
\text { Left-Wing Voters }\end{array}$ & $\begin{array}{c}\text { Unweighted } \\
\text { Control for Ballot } \\
\text { Accepted (Yes/No), } \\
\text { Turnout-Gap and } \\
\text { Share Empty Votes }\end{array}$ & \\
\hline Number of Votes & 92 & 92 & 92 & 92 & \\
\hline R-Squared & 0.462 & 0.366 & 0.398 & 0.566 & \\
\hline H0: Equality of estimated coefficients (P-Value): & 0.0000 & 0.0000 & 0.0000 & 0.0000 & \\
\hline
\end{tabular}

Notes: The dependent variable in (1) to (4) is the difference between a ballot's approval in the survey ("stated share yes") and true approval as measured at the ballot box ("real share yes"). The number in (5) is the share of votes per policy area, where the left-wing party recommended a "yes". Standard errors clustered at the voting day level in parantheses. ${ }^{\star \star \star}$ denote significance at the $1 \%$ level, ${ }^{*}$ significance at the $5 \%$ level, and ${ }^{*}$ significance at the $10 \%$ level. 
TABLE 3

Liberal Bias

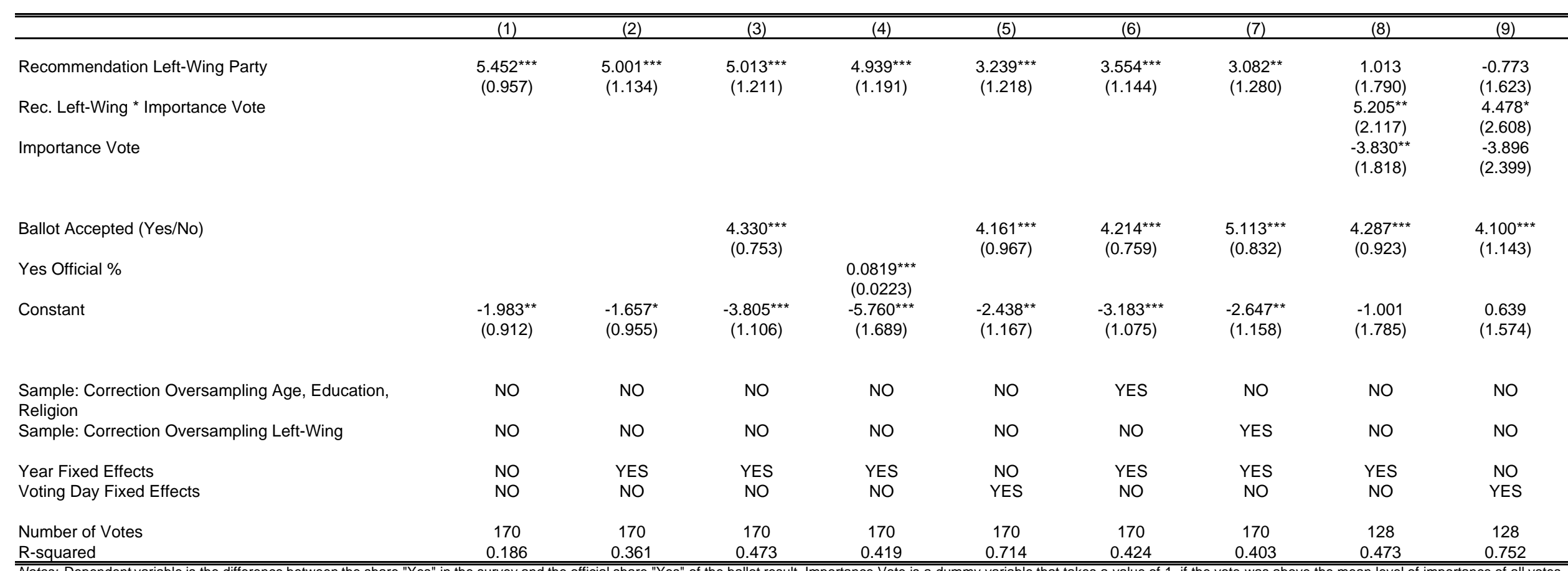

Notes: Dependent variable is the difference between the share "Yes" in the survey and the official share "Yes" of the ballot result. Importance Vote is a dummy variable that takes a value of 1, if the vote was above the mean level of importance of all votes,

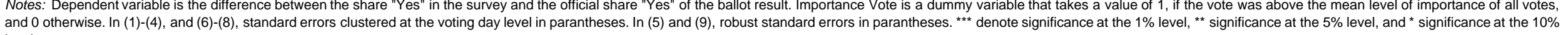

level. 
TABLE 4

Acceptance of Ballot and Positive Survey Bias

(1)

(2)

(3)

(4)

(5)

(6)

(7)

(8)

(9)

Vote Accepted

$\begin{array}{cc}4.829^{\star \star \star} & 4.172^{\star \star \star} \\ (0.828) & (0.718)\end{array}$

Yes Official

Recommendation Left-Wing Party

Constant

$\begin{array}{cc}-0.583 & 4.271 \\ (0.733) & (2.565)\end{array}$

2.911
$(2.954)$

$5.496 * \star \star$

(1.469)

$4.330^{\star * \star}$

$4.600 * * \star$
$(0.845)$

$4.575^{\star \star \star}$

$\begin{array}{cc}0.0799 * \star * & -0.0416 \\ (0.0222) & (0.0431)\end{array}$

$5.013^{\star \star \star} \quad 4.285^{\star \star \star} \quad 2.651^{\star}$

(1.211) (1.416) (1.401)

$(0.733) \quad(2.565)$

$5.584^{\star}$
$(2.809)$

0.577
$(2.036)$

0.756

$-2.595^{\star}$

$-0.922$

(1.936)

0.546

(2.148)

Control Topics

Year Fixed Effect

Voting Day Fixed Effects

$\begin{array}{lllllllll}N O & \text { NO } & \text { NO } & \text { NO } & \text { NO } & \text { YES } & \text { YES } & \text { NO } & \text { NO } \\ \text { NO } & \text { YES } & \text { YES } & \text { YES } & \text { YES } & \text { YES } & \text { NO } & \text { NO } & \text { NO } \\ \text { NO } & \text { NO } & \text { NO } & \text { NO } & \text { NO } & \text { NO } & \text { YES } & \text { NO } & \text { NO }\end{array}$

Sample

Full Full Full

Full

Full

Full

Full

Full

Narrow

Narrow $M$
$45-55$
36

0.213

0.530

0.745

184
0.288

0.341

0.473

NO

NO

R-squared yes"). Vote accepted is a dummy variable taking a value of 1 if the ballot was approved by the Swiss electorate. Yes Official is the share of yes votes by the Swiss electorate. Recommendation Left-Wing Party is a dummy variable taking a value of 1 if the left-wing party recommended to accept the ballot. Column (8) restricts the sample to the votes that were accepted or rejected at a narrow margin (i.e. approval between 45 and 55\%). Column (9) presents a placebo test, where the sample is restricted to votes that were narrowly rejected (share yes between 40 and 50\%). Vote Accepted in this placebo test is a dummy variable that takes a value of 1 if the approval is bigger than 45 percent. Standard errors clustered at the voting day level in parantheses. ${ }^{\star \star \star}$ denote significance at the $1 \%$ level, ${ }^{* \star}$ significance at the $5 \%$ level, and * significance at the $10 \%$ level. 
TABLE 5

Deviations from Party Recommendations

\begin{tabular}{|c|c|c|c|c|c|c|c|c|}
\hline & $\begin{array}{c}(1) \\
\text { Prob. }\end{array}$ & (2) & (3) & $\begin{array}{c}(4) \\
\text { Deviation }\end{array}$ & $\begin{array}{c}(5) \\
\text { from Party Recom }\end{array}$ & $\begin{array}{c}(6) \\
\text { nendations }\end{array}$ & $\overline{~(7) ~}$ & $\overline{(8)}$ \\
\hline & Yes L & Left (SP) & Middle (CVP) & Right (FDP) & Ultra Right (SVP) & 4 Big Parties & 4 Big Parties & 4 Big Parties \\
\hline Vote Accepted & $\begin{array}{c}0.360^{\star \star \star} \\
(0.00449)\end{array}$ & $\begin{array}{l}0.283^{\star \star \star} \\
(0.0334)\end{array}$ & $\begin{array}{l}0.174^{\star \star *} \\
(0.0269)\end{array}$ & $\begin{array}{l}0.347^{\star \star \star} \\
(0.0418)\end{array}$ & $\begin{array}{l}0.125^{\star \star} \\
(0.0593)\end{array}$ & $\begin{array}{l}0.235^{\star \star \star} \\
(0.0179)\end{array}$ & $\begin{array}{l}0.124^{\star \star \star} \\
(0.0435)\end{array}$ & $\begin{array}{c}0.131 \\
(0.0798)\end{array}$ \\
\hline Constant & $\begin{array}{c}0.346^{\star \star \star} \\
(0.00252)\end{array}$ & $\begin{array}{l}0.178^{\star \star \star} \\
(0.0153)\end{array}$ & $\begin{array}{l}0.165^{\star \star \star} \\
(0.00923)\end{array}$ & $\begin{array}{l}0.182^{\star \star \star} \\
(0.00663)\end{array}$ & $\begin{array}{l}0.242^{\star \star \star} \\
(0.00811)\end{array}$ & $\begin{array}{l}0.190^{\star \star \star} \\
(0.00494)\end{array}$ & $\begin{array}{l}0.250 * \star \star \\
(0.0190)\end{array}$ & $\begin{array}{l}0.244 * \star \star \\
(0.0344)\end{array}$ \\
\hline $\begin{array}{l}\text { Individual Fixed Effects } \\
\text { Votes }\end{array}$ & $\begin{array}{l}\text { Yes } \\
\text { All }\end{array}$ & $\begin{array}{l}\text { Yes } \\
\text { All }\end{array}$ & $\begin{array}{l}\text { Yes } \\
\text { All }\end{array}$ & $\begin{array}{r}\text { Yes } \\
\text { All }\end{array}$ & $\begin{array}{l}\text { Yes } \\
\text { All }\end{array}$ & $\begin{array}{l}\text { Yes } \\
\text { All }\end{array}$ & $\begin{array}{c}\text { Yes } \\
\text { Margin 40-60 }\end{array}$ & $\begin{array}{c}\text { Yes } \\
\text { Margin 45-55 }\end{array}$ \\
\hline $\begin{array}{l}\text { Observations } \\
\text { R-squared }\end{array}$ & $\begin{array}{c}98,604 \\
0.568\end{array}$ & $\begin{array}{l}4,294 \\
0.837 \\
\end{array}$ & $\begin{array}{l}4,940 \\
0.637 \\
\end{array}$ & $\begin{array}{l}5,124 \\
0.753 \\
\end{array}$ & $\begin{array}{l}3,346 \\
0.724 \\
\end{array}$ & $\begin{array}{c}17,704 \\
0.742 \\
\end{array}$ & $\begin{array}{l}5,293 \\
0.895 \\
\end{array}$ & $\begin{array}{l}2,555 \\
0.954\end{array}$ \\
\hline
\end{tabular}


TABLE 6

Canton Characteristics and Survey Biases (in Absolute Values)

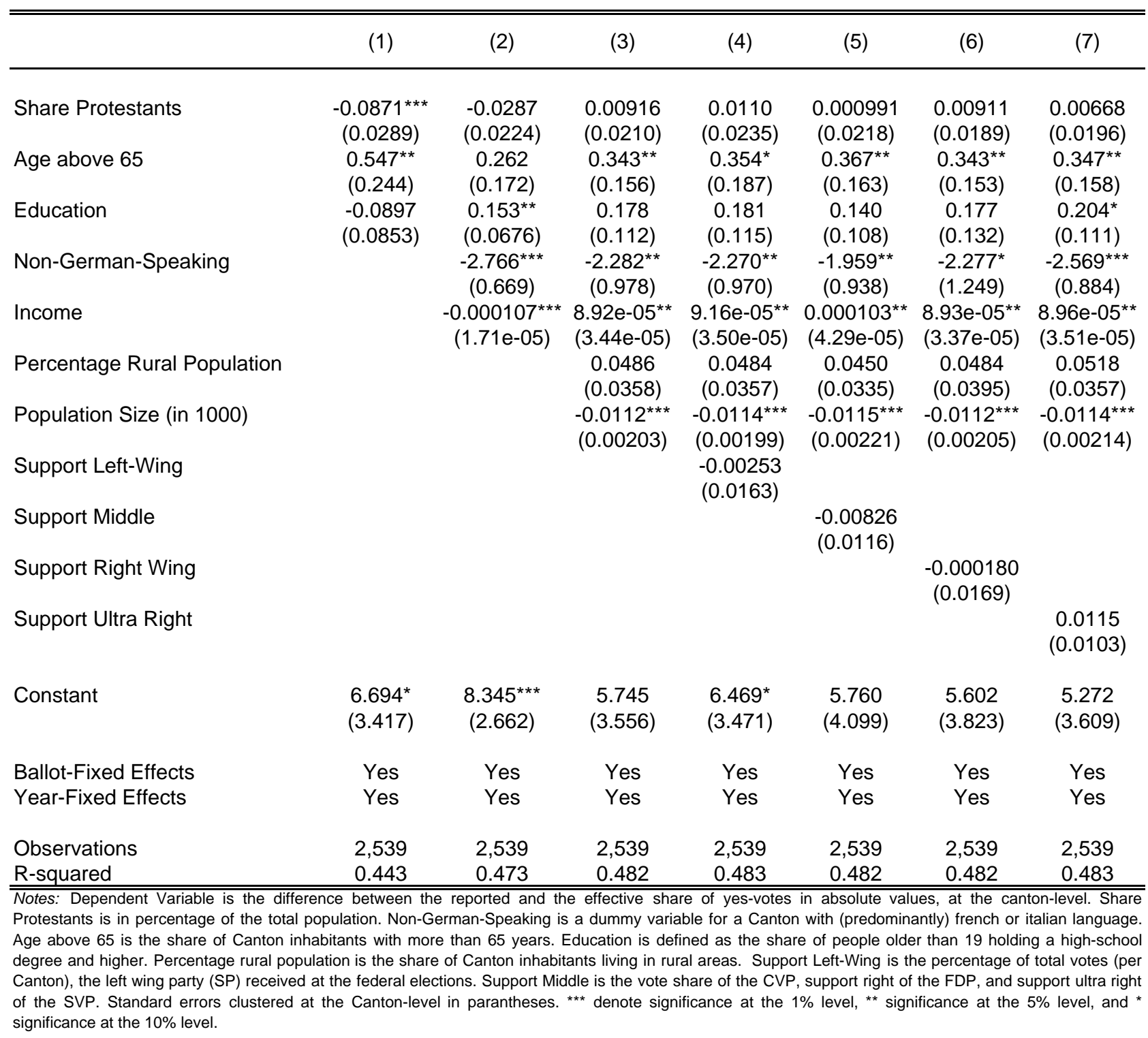


APPENDIX TABLE 1

Summary Statistics, VOX Samples

\begin{tabular}{|c|c|c|c|c|c|}
\hline & Obs. & Mean & Std. Dev. & Min & Max \\
\hline Share Women (\%) & 184 & 50.7 & 1.7 & 48.1 & 55.3 \\
\hline Share Protestants (\%) & 184 & 42.5 & 3.7 & 33.4 & 49.5 \\
\hline Share Catholics (\%) & 184 & 42.8 & 2.9 & 36.9 & 50.3 \\
\hline Age $20-39(\%)$ & 184 & 36.7 & 3.4 & 28.2 & 43.2 \\
\hline Age $40-59(\%)$ & 184 & 34.4 & 1.6 & 30.4 & 37.4 \\
\hline Age 60plus (\%) & 184 & 26.7 & 3.9 & 20.4 & 33.8 \\
\hline Higher Education (\%) & 184 & 33.0 & 7.0 & 20.9 & 51.7 \\
\hline Linguistic Area: Geman (\%) & 183 & 70.6 & 1.4 & 68.5 & 75.0 \\
\hline Linguistic Area: French (\%) & 183 & 23.8 & 1.1 & 20.0 & 26.4 \\
\hline Linguistic Area: Italian (\%) & 181 & 5.5 & 0.8 & 2.0 & 6.7 \\
\hline Survey Bias (\%) & 184 & 1.85 & 5.80 & -15.19 & 17.93 \\
\hline Survey Bias (Absolute Value) (\%) & 184 & 4.67 & 3.90 & 0.02 & 17.93 \\
\hline Turnout Gap (\%) & 184 & 9.22 & 5.33 & -12.91 & 22.68 \\
\hline Non-Cooperation Rate (\%) & 74 & 63.85 & 6.13 & 52.00 & 74.80 \\
\hline Share Left-Wing Voters (\%) & 184 & 29.98 & 5.16 & 21.82 & 42.66 \\
\hline Share Middle Voters (\%) & 184 & 14.95 & 3.51 & 8.13 & 23.16 \\
\hline Share Right-Wing Voters (\%) & 184 & 21.53 & 3.60 & 14.96 & 30.25 \\
\hline Share Ultra Right-Wing Voters (\%) & 184 & 17.33 & 6.47 & 7.07 & 29.95 \\
\hline Share Emtpy Votes (\%) & 184 & 11.03 & 8.41 & 1.03 & 60.34 \\
\hline Importance Vote & 138 & 6.75 & 0.90 & 4.35 & 8.48 \\
\hline \multicolumn{6}{|c|}{$\begin{array}{l}\text { Notes: The variables are averages per vote. Survey Bias is the difference between the Share Yes in the Survey } \\
\text { and the Share Yes of the voting result. Turnout Gap is the difference between Turnout in the Survey and official } \\
\text { Turnout at the ballot. Non-Cooperation Rate is the Share of contacted people who refused to participate in the VOX- } \\
\text { Survey. Share Left Wing Voters is the share of voters with the socialist party (SP) as their favourite party (in \% of } \\
\text { voters which indicated a favourite party); share Middle Voters the respective share of CVP Voters; share Right- } \\
\text { Wing Voters the respective share of FDP Voters; share Ultra-Right-Wing Voters the respective share of SVP } \\
\text { Voters. Share Empty Votes is the share of votes (per ballot) that were left blank by the voters. Importance Vote is a } \\
\text { dummy variable that takes a value of } 1 \text {, if the vote was above the mean level of importance of all votes, and } 0 \\
\text { otherwise. }\end{array}$} \\
\hline
\end{tabular}


APPENDIX TABLE 2

Votes, sorted by Difference Share-Yes (Survey - Result Real)

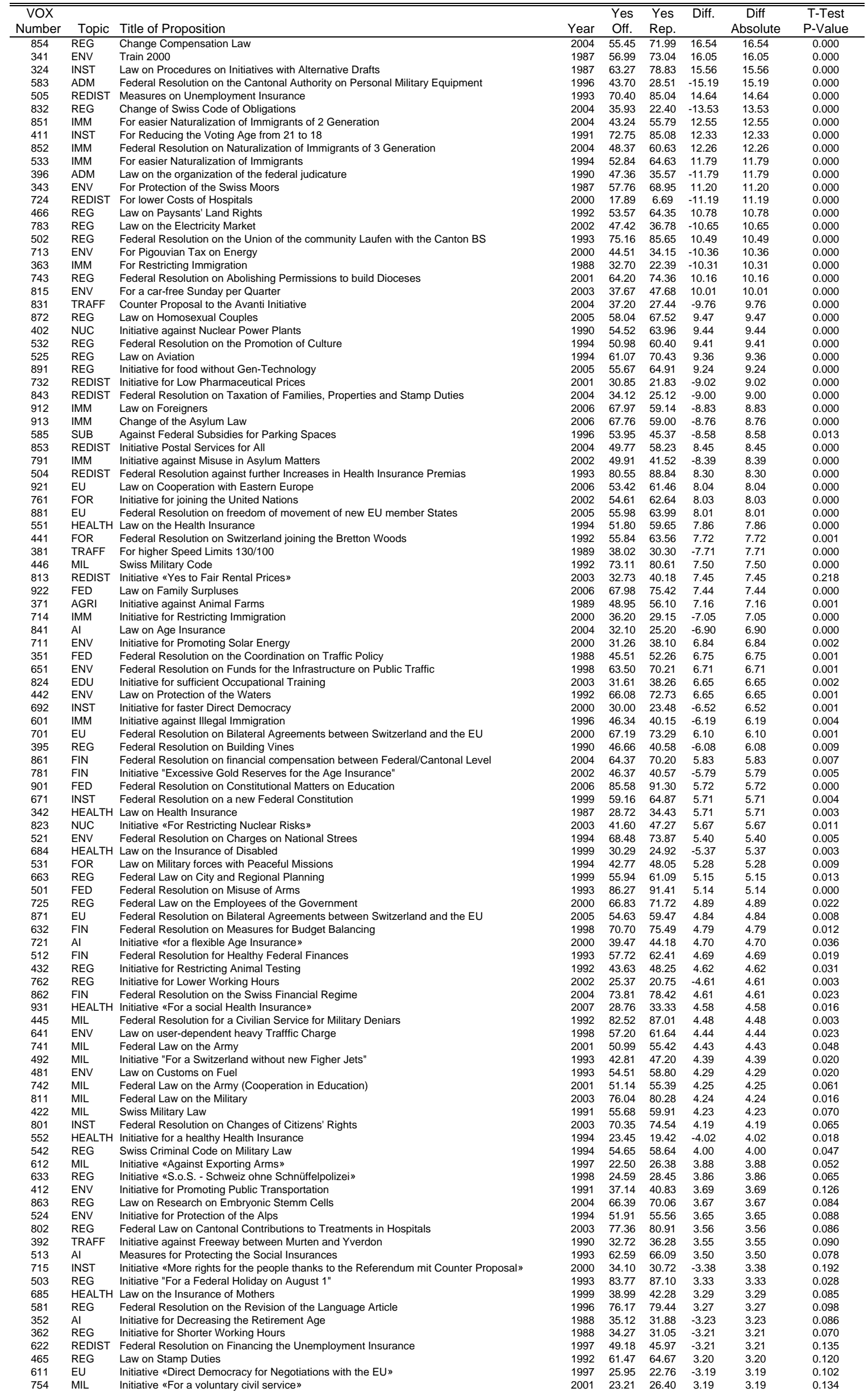




\begin{tabular}{|c|c|c|c|c|c|c|c|c|}
\hline 461 & ENV & Federal Resolution on Building the Swiss Railway & 1992 & 63.61 & 66.72 & 3.11 & 3.11 & 0.104 \\
\hline 613 & MIL & Against Federal Regulations on Gun Powder & 1997 & 82.18 & 85.18 & 3.00 & 3.00 & 0.108 \\
\hline 661 & INST & Federal Resolution on the Eligibility in the Federal Council & 1999 & 74.67 & 77.67 & 2.99 & 2.99 & 0.079 \\
\hline 514 & FIN & Federal Resolution on Consumption Taxes & 1993 & 60.65 & 63.57 & 2.92 & 2.92 & 0.153 \\
\hline 753 & MIL & Initiative «for a Switzerland without Army» & 2001 & 21.90 & 24.75 & 2.84 & 2.84 & 0.144 \\
\hline 822 & NUC & Initiative «Against Nuclear Power Plants» & 2003 & 33.71 & 36.51 & 2.79 & 2.79 & 0.166 \\
\hline 401 & NUC & Initiative against Nuclear Energy & 1990 & 47.13 & 49.91 & 2.78 & 2.78 & 0.186 \\
\hline 652 & AGRI & Federal Resolution on a new Corn Article & 1998 & 79.43 & 82.20 & 2.77 & 2.77 & 0.140 \\
\hline 892 & REG & Federal Law on Opening Hours of Shops & 2005 & 50.56 & 53.30 & 2.74 & 2.74 & 0.184 \\
\hline 752 & $\mathrm{Al}$ & Initiative «for a secure Age Insurance» & 2001 & 22.86 & 20.32 & -2.54 & 2.54 & 0.184 \\
\hline 573 & REG & Law on Aquisition of Property through Foreigners & 1995 & 46.44 & 48.95 & 2.52 & 2.52 & 0.265 \\
\hline 523 & ENV & Federal Resolution on usage-dependent Traffic Road Charges & 1994 & 67.14 & 69.62 & 2.48 & 2.48 & 0.223 \\
\hline 393 & TRAFF & Initiative against Freeway in the Knonauer Amt & 1990 & 31.37 & 33.84 & 2.48 & 2.48 & 0.239 \\
\hline 792 & REDIST & Federal Law on the Unemployment Insurance & 2002 & 56.10 & 53.74 & -2.36 & 2.36 & 0.287 \\
\hline 431 & HEALTH & Initiative for a cheap Health Insurance & 1992 & 39.27 & 41.60 & 2.34 & 2.34 & 0.280 \\
\hline 712 & ENV & For promoting renewable Energies & 2000 & 45.28 & 42.98 & -2.30 & 2.30 & 0.310 \\
\hline 911 & $\mathrm{Al}$ & Initiative «Profits of the Swiss National Bank into the Age Insurance» & 2006 & 41.74 & 39.47 & -2.27 & 2.27 & 0.279 \\
\hline 821 & HEALTH & Initiative «Equal Rights for Disables» & 2003 & 37.65 & 35.38 & -2.26 & 2.26 & 0.195 \\
\hline 642 & AGRI & Initiative «for cheap aliments and ecological agriculture» & 1998 & 22.99 & 20.77 & -2.22 & 2.22 & 0.198 \\
\hline 782 & FIN & Counterproposal Initiative "Excessive Gold Reserves for AHV" & 2002 & 46.39 & 44.24 & -2.15 & 2.15 & 0.314 \\
\hline 483 & REG & Initiative against Animal Experiments & 1993 & 27.77 & 29.91 & 2.15 & 2.15 & 0.222 \\
\hline 664 & REG & Federal Resolution on Regulating Transplantation Medicine & 1999 & 87.77 & 89.85 & 2.08 & 2.08 & 0.114 \\
\hline 394 & TRAFF & Initiative against Freeway between Biel and Solothurn/Zuchwil & 1990 & 34.04 & 36.08 & 2.04 & 2.04 & 0.323 \\
\hline 602 & REG & Federal Law regulating working conditions & 1996 & 32.97 & 30.97 & -2.00 & 2.00 & 0.310 \\
\hline 592 & ADM & Law on the Organization of the Executive and Administration & 1996 & 39.39 & 37.41 & -1.98 & 1.98 & 0.410 \\
\hline 491 & MIL & Initiative "No more than 40 places for Arms" & 1993 & 44.71 & 46.59 & 1.88 & 1.88 & 0.315 \\
\hline 421 & FIN & Federal Resolution on Reorganizing the Federal Finances & 1991 & 45.65 & 43.81 & -1.84 & 1.84 & 0.452 \\
\hline 443 & ENV & Initiative for Saving the Waters & 1992 & 37.06 & 38.83 & 1.78 & 1.78 & 0.429 \\
\hline 482 & REG & Federal Resolution on Gambling Houses & 1993 & 72.46 & 74.16 & 1.70 & 1.70 & 0.313 \\
\hline 511 & FIN & Federal Resolution on Federal Finances & 1993 & 66.66 & 68.30 & 1.64 & 1.64 & 0.404 \\
\hline 842 & $\mathrm{Al}$ & Federal Resolution on Financement of the Age Insurance through higher Taxes & 2004 & 31.42 & 29.81 & -1.61 & 1.61 & 0.385 \\
\hline 683 & HEALTH & Federal Resolution on Medical Prescription for Heroine & 1999 & 54.42 & 56.01 & 1.59 & 1.59 & 0.415 \\
\hline 654 & REG & Federal Law regulating working conditions & 1998 & 63.38 & 64.94 & 1.56 & 1.56 & 0.506 \\
\hline 471 & EU & Federal Resolution on the European Economic Area & 1992 & 49.66 & 51.22 & 1.55 & 1.55 & 0.373 \\
\hline 404 & TRAFF & Law on Road Traffic & 1990 & 52.80 & 51.28 & -1.51 & 1.51 & 0.479 \\
\hline 563 & AGRI & Law on Farming & 1995 & 33.59 & 35.05 & 1.46 & 1.46 & 0.496 \\
\hline 382 & MIL & Initiative for a Switzerland without Army & 1989 & 35.59 & 37.04 & 1.44 & 1.44 & 0.414 \\
\hline 621 & HEALTH & Initiative "Youth Without Drugs" & 1997 & 29.34 & 27.96 & -1.39 & 1.39 & 0.480 \\
\hline 561 & AGRI & Counterproposal to the Initiative «for an ecological and effective agriculture» & 1995 & 49.12 & 47.74 & -1.38 & 1.38 & 0.540 \\
\hline 643 & Al & Initiative «10th Revision of the Age Insurance without increasing the Retirement Age» & 1998 & 41.48 & 40.17 & -1.31 & 1.31 & 0.508 \\
\hline 691 & INST & Federal Resolution on the Reform of the Judiciary & 2000 & 86.36 & 85.06 & -1.30 & 1.30 & 0.433 \\
\hline 391 & TRAFF & Initiative for Restricting Road Making & 1990 & 28.51 & 29.81 & 1.30 & 1.30 & 0.515 \\
\hline 731 & EU & Initiative «Yes to Europe!» & 2001 & 23.15 & 24.44 & 1.28 & 1.28 & 0.445 \\
\hline 733 & TRAFF & Initiative «for a better security on the strees with speed limit 30» & 2001 & 20.30 & 19.03 & -1.28 & 1.28 & 0.392 \\
\hline 323 & INST & Initiative for Direct Democracy in Military Expenses & 1987 & 40.56 & 41.78 & 1.22 & 1.22 & 0.591 \\
\hline 723 & MIL & Initiative «Saving in the Military» & 2000 & 37.62 & 36.40 & -1.22 & 1.22 & 0.591 \\
\hline 515 & HEALTH & Initiative for Reducing Problems with Alcohol & 1993 & 25.26 & 24.05 & -1.20 & 1.20 & 0.473 \\
\hline 693 & REG & Initiative «for a fair Representation of Women in the Government» & 2000 & 17.97 & 19.15 & 1.18 & 1.18 & 0.527 \\
\hline 751 & FIN & Federal Resolution promoting a Debt Break & 2001 & 84.74 & 83.58 & -1.16 & 1.16 & 0.510 \\
\hline 833 & REG & Initiative «Stricter Regulation for Sexual Offenders» & 2004 & 56.19 & 57.34 & 1.14 & 1.14 & 0.578 \\
\hline 444 & REG & Counterproposal to the Initiative "Against Misuse in Gentechnology" & 1992 & 73.83 & 72.71 & -1.12 & 1.12 & 0.588 \\
\hline 694 & REG & Initiative «against Manipulations in the Technology of Reproduction» & 2000 & 28.24 & 27.23 & -1.01 & 1.01 & 0.642 \\
\hline 322 & IMM & Law on Residence of Foreigners & 1987 & 65.71 & 66.60 & 0.89 & 0.89 & 0.674 \\
\hline 772 & HEALTH & Initiative «Protection of Mother and Baby» & 2002 & 18.25 & 19.11 & 0.87 & 0.87 & 0.605 \\
\hline 516 & HEALTH & Initiative for Reducing Problems with Tabacco & 1993 & 25.52 & 24.71 & -0.81 & 0.81 & 0.653 \\
\hline 361 & REG & Initiative against Speculation with Properties & 1988 & 30.78 & 31.55 & 0.77 & 0.77 & 0.682 \\
\hline 722 & $\mathrm{Al}$ & Initiative «for a flexible Retirement Age» & 2000 & 46.02 & 46.79 & 0.77 & 0.77 & 0.725 \\
\hline 403 & ENV & Federal Resolution on the Energy Article & 1990 & 71.10 & 71.80 & 0.70 & 0.70 & 0.718 \\
\hline 562 & AGRI & Resolution on Dairy Farming & 1995 & 36.53 & 37.23 & 0.70 & 0.70 & 0.736 \\
\hline 564 & FIN & Law on Reducing Federal Expenses & 1995 & 83.38 & 83.94 & 0.56 & 0.56 & 0.745 \\
\hline 695 & ENV & Initiative «for cutting motorized Road Traffic into Half» & 2000 & 21.33 & 20.79 & -0.54 & 0.54 & 0.783 \\
\hline 771 & HEALTH & Law Regulating Abortion & 2002 & 72.15 & 72.68 & 0.52 & 0.52 & 0.807 \\
\hline 631 & REG & Initiative «for Protection against Gen-Manipulation» & 1998 & 33.29 & 33.81 & 0.52 & 0.52 & 0.799 \\
\hline 814 & HEALTH & Initiative «For resaonable Health Costs» & 2003 & 27.09 & 27.60 & 0.51 & 0.51 & 0.803 \\
\hline 591 & AGRI & Counterproposal to the Initiative «for a natural agriculture» & 1996 & 77.59 & 78.08 & 0.49 & 0.49 & 0.816 \\
\hline 582 & REG & Federal Resolution on the union of the community Vellerat with the Canton JU & 1996 & 91.64 & 92.12 & 0.48 & 0.48 & 0.699 \\
\hline 572 & $\mathrm{Al}$ & Initiative for better Age Insurance & 1995 & 27.64 & 27.21 & -0.42 & 0.42 & 0.853 \\
\hline 681 & IMM & Asylum Law & 1999 & 70.59 & 70.99 & 0.40 & 0.40 & 0.832 \\
\hline 682 & IMM & Federal Resolution on Urgent Matters in the Area of Asylum & 1999 & 70.84 & 70.46 & -0.38 & 0.38 & 0.861 \\
\hline 553 & IMM & Law on mandatory measures in Immigration Law & 1994 & 72.91 & 72.55 & -0.35 & 0.35 & 0.852 \\
\hline 755 & TAX & Initiative «for Taxation of Capital Gains» & 2001 & 34.11 & 34.37 & 0.26 & 0.26 & 0.905 \\
\hline 941 & HEALTH & Law on Insurance against Disability & 2007 & 59.09 & 58.83 & -0.26 & 0.26 & 0.898 \\
\hline 653 & HEALTH & Initiative «for a reasonable drug policy» & 1998 & 26.01 & 26.25 & 0.24 & 0.24 & 0.899 \\
\hline 321 & IMM & Asylum Law & 1987 & 67.34 & 67.52 & 0.18 & 0.18 & 0.914 \\
\hline 584 & REG & Against the Federal Duty to buy Spirits & 1996 & 80.80 & 80.98 & 0.18 & 0.18 & 0.951 \\
\hline 812 & REG & Federal Law on Civil Protection & 2003 & 80.56 & 80.43 & -0.13 & 0.13 & 0.923 \\
\hline 541 & AGRI & Against Subsidies for Corn Production & 1994 & 64.59 & 64.71 & 0.11 & 0.11 & 0.959 \\
\hline 522 & ENV & Federal Resolution on Traffic Road Charges & 1994 & 72.23 & 72.24 & 0.02 & 0.02 & 0.982 \\
\hline 571 & $\mathrm{Al}$ & Law on Age Insurance & 1995 & 60.71 & 60.73 & 0.02 & 0.02 & 0.990 \\
\hline 662 & REDIST & Initiative «Proprietary for Everybody» & 1999 & 41.32 & 41.32 & 0.00 & 0.00 & 0.991 \\
\hline
\end{tabular}


APPENDIX TABLE 3

Description Policy Areas

\begin{tabular}{|c|c|c|c|c|}
\hline Policy Area & $\begin{array}{l}\text { Number } \\
\text { of Votes }\end{array}$ & $\begin{array}{l}\text { Content } \\
\text { Votes }\end{array}$ & $\begin{array}{l}\text { VOX Number } \\
\text { Votes }\end{array}$ & \\
\hline International Integration & 10 & $\begin{array}{c}\text { Relationship with the European } \\
\text { Union, Joining International } \\
\text { Organizations (Bretton Woods, } \\
\text { UN) }\end{array}$ & $\begin{array}{c}441,471,531,701 \\
731,761,871,881 \\
921\end{array}$ & PRO \\
\hline Facilitated Immigration & 12 & $\begin{array}{l}\text { Votes on Restricting/Facilitating } \\
\text { Immigration }\end{array}$ & $\begin{array}{l}533,851,852,912 \\
363,553,601,681 \\
682,714,791,913\end{array}$ & $\begin{array}{l}\text { PRO } \\
\text { CONTRA }\end{array}$ \\
\hline Increase Army & 11 & $\begin{array}{c}\text { Votes that target at } \\
\text { strengthening/weakening the } \\
\text { Swiss Army }\end{array}$ & $\begin{array}{l}382,422,445,491 \\
492,612,723,753 \\
754,811\end{array}$ & CONTRA \\
\hline Protection Environment & 23 & $\begin{array}{l}\text { Votes that target at protecting the } \\
\text { environment, mostly by } \\
\text { regulations, financial incentives } \\
\text { (charges, taxes) and traffic policy }\end{array}$ & $\begin{array}{c}341,343,391,392 \\
393,394,403,412 \\
442,443,461,481 \\
521,522,523,524 \\
641,651,695,711 \\
712,713,815\end{array}$ & PRO \\
\hline Nucler Energy & 4 & $\begin{array}{l}\text { Votes that prohibit building new } \\
\text { power plants, or ask to shut } \\
\text { down all existing powerplants }\end{array}$ & $401,402,822,823$ & CONTRA \\
\hline Budget Balance & 2 & $\begin{array}{c}\text { Measures to reduce the Federal } \\
\text { Deficit }\end{array}$ & 564,632 & PRO \\
\hline Direct Democracy & 5 & $\begin{array}{l}\text { Measures to extend/facilitate } \\
\text { direct democratic participation }\end{array}$ & $323,324,692,715,801$ & PRO \\
\hline Liberal Policies Health & 8 & $\begin{array}{l}\text { Votes with more/less } \\
\text { liberalization in the health sector: } \\
\text { working conditions for women, }\end{array}$ & $\begin{array}{c}342,653,683,685 \\
771 \\
515,516,772\end{array}$ & $\begin{array}{l}\text { PRO } \\
\text { CONTRA }\end{array}$ \\
\hline Redistribution & 7 & $\begin{array}{c}\text { Subsidies Health Premia, } \\
\text { Regulations Rental and Postal } \\
\text { Service Market }\end{array}$ & $\begin{array}{c}551,431,552,931 \\
853,813\end{array}$ & PRO \\
\hline Increase Retirement Age & 7 & $\begin{array}{l}\text { Votes with the goal of } \\
\text { increasing/decreasing the } \\
\text { retirement age }\end{array}$ & $\begin{array}{c}571,841 \\
352,572,643,721,722\end{array}$ & CONTRA \\
\hline Gender Equality & 3 & $\begin{array}{l}\text { Improve conditions for working } \\
\text { women after giving birth to a } \\
\text { child, Introduce gender quota for } \\
\text { the federal parliament and } \\
\text { judiciary. }\end{array}$ & $685,693,854$ & PRO \\
\hline Liberal Attitudes & 2 & $\begin{array}{l}\text { Regulation Sexual Acts } \\
\text { Teenagers, Rights for } \\
\text { Homosexual Couples }\end{array}$ & 446,872 & PRO \\
\hline
\end{tabular}

